\title{
Influence of High Hemoglobin-Oxygen Affinity on Humans During Hypoxia
}

\author{
Kevin L. Webb ${ }^{1}$, Paolo B. Dominelli', Sarah E. Baker', Stephen A. Klassen ${ }^{1,3}$, \\ Michael J. Joyner ${ }^{1}$, Jonathon W. Senefeld ${ }^{1+}$ and Chad C. Wiggins ${ }^{1 * \dagger}$ \\ ${ }^{1}$ Department of Anesthesiology and Perioperative Medicine, Mayo Clinic, Rochester, MN, United States, ${ }^{2}$ Department \\ of Kinesiology, University of Waterloo, Waterloo, ON, Canada, ${ }^{3}$ Department of Kinesiology, Brock University, St. Catharines, \\ ON, Canada
}

OPEN ACCESS

Edited by:

Tatum S. Simonson, University of California, San Diego,

United States

Reviewed by:

Heimo Mairbäurl, Heidelberg University Hospital,

Germany

Catherine M. Ivy,

Western University, Canada

Martin Burtscher,

University of Innsbruck, Austria

Jean-Paul R- Richalet,

Université Sorbonne Paris Nord,

France

*Correspondence:

Chad C. Wiggins

Wiggins.Chad@mayo.edu

${ }^{t}$ These authors have contributed

equally to this work

Specialty section:

This article was submitted to Integrative Physiology, a section of the journal

Frontiers in Physiology

Received: 24 August 2021

Accepted: 22 December 2021

Published: 14 January 2022

Citation:

Webb KL, Dominelli $P B$,

Baker SE, Klassen SA, Joyner MJ, Senefeld JW and Wiggins CC (2022) Influence of High Hemoglobin-Oxygen

Affinity on Humans During Hypoxia.

Front. Physiol. 12:763933.

doi: 10.3389/fphys.2021.763933
Humans elicit a robust series of physiological responses to maintain adequate oxygen delivery during hypoxia, including a transient reduction in hemoglobin-oxygen $\left(\mathrm{Hb}-\mathrm{O}_{2}\right)$ affinity. However, high $\mathrm{Hb}-\mathrm{O}_{2}$ affinity has been identified as a beneficial adaptation in several species that have been exposed to high altitude for generations. The observed differences in $\mathrm{Hb}_{2} \mathrm{O}_{2}$ affinity between humans and species adapted to high altitude pose a central question: is higher or lower $\mathrm{Hb}-\mathrm{O}_{2}$ affinity in humans more advantageous when $\mathrm{O}_{2}$ availability is limited? Humans with genetic mutations in hemoglobin structure resulting in high $\mathrm{Hb}-\mathrm{O}_{2}$ affinity have shown attenuated cardiorespiratory adjustments during hypoxia both at rest and during exercise, providing unique insight into this central question. Therefore, the purpose of this review is to examine the influence of high $\mathrm{Hb}-\mathrm{O}_{2}$ affinity during hypoxia through comparison of cardiovascular and respiratory adjustments elicited by humans with high $\mathrm{Hb}^{-\mathrm{O}_{2}}$ affinity compared to those with normal $\mathrm{Hb}-\mathrm{O}_{2}$ affinity.

Keywords: altitude acclimatization, high-altitude, oxygen transport, exercise, $\dot{\mathrm{V}}_{2 \max }$ (maximal oxygen uptake), high affinity hemoglobin $(\mathrm{Hb})$

\section{INTRODUCTION}

Currently, there is ongoing debate about the advantages of higher or lower hemoglobin-oxygen $\left(\mathrm{Hb}-\mathrm{O}_{2}\right)$ affinity in humans, particularly during hypoxia (Dempsey, 2020). A decrease in $\mathrm{Hb}-\mathrm{O}_{2}$ affinity is often observed among humans during acclimatization to altitudes ranging from 2500 to $4500 \mathrm{~m}$, presumably to facilitate $\mathrm{O}_{2}$ off-loading and protect against tissue hypoxia (Hall et al., 1936; Aste-Salazar and Hurtado, 1944; Lenfant and Sullivan, 1971). In contrast, several animal species adapted to high-altitude environments display a higher $\mathrm{Hb}-\mathrm{O}_{2}$ affinity compared to that of lowland counterparts (Bartels et al., 1963; Monge and Leon-Velarde, 1991; Weber et al., 1993; Scott and Milsom, 2007; Storz et al., 2010; Storz, 2016; Natarajan et al., 2018). These divergent observations lead to the central question of this review, is higher or lower $\mathrm{Hb}-\mathrm{O}_{2}$ affinity more advantageous for humans during hypoxia?

Humans rely on a continuous supply of $\mathrm{O}_{2}$ for metabolism. Oxygen binds to hemoglobin in the lungs and travels through the large arteries, arterioles, and finally the small capillaries supplying peripheral tissue (Scholander, 1960). Although in vitro $\mathrm{Hb}-\mathrm{O}_{2}$ affinity is characterized by a single curve or metric (e.g., $\mathrm{P}_{50}$, as described below), the in vivo $\mathrm{Hb}-\mathrm{O}_{2}$ affinity cannot be described as 
simply. Within the vasculature, alterations of modulatory factors such as temperature, $\mathrm{pH}$, and the concentration of carbon dioxide $\left(\mathrm{CO}_{2}\right)$ lead to transient changes in $\mathrm{Hb}-\mathrm{O}_{2}$ affinity during circulatory transit, which directly impact $\mathrm{O}_{2}$ loading at the lung and $\mathrm{O}_{2}$ off-loading in peripheral tissue (Jensen, 2004; Winslow, 2007). Changes in $\mathrm{Hb}-\mathrm{O}_{2}$ affinity can be transient or chronic due to a variety of conditions such as genetic mutations, disease, altitude acclimatization, or age (Woodson et al., 1970; Humpeler and Amor, 1973; Versmold et al., 1973; Winslow, 2007). For example, evidence suggests that some groups of humans native to high altitude have a greater $\mathrm{Hb}-\mathrm{O}_{2}$ affinity than sea-level residents (Simonson et al., 2014; Li et al., 2018). Although the mechanisms underlying the adaptive increase of $\mathrm{Hb}-\mathrm{O}_{2}$ affinity among highaltitude natives are not well understood, a number of genetic mutations in hemoglobin structure that contribute to a systemic increase in $\mathrm{Hb}-\mathrm{O}_{2}$ affinity in humans have been identified (Mangin, 2017), predominantly among low-altitude residents. Humans with mutations resulting in high $\mathrm{Hb}-\mathrm{O}_{2}$ affinity may provide unique insight to the ongoing debate regarding the advantages and disadvantages of high $\mathrm{Hb}-\mathrm{O}_{2}$ affinity during hypoxia. Past investigations of the cardiorespiratory adjustments to hypoxic exposure at rest and during exercise suggest that high $\mathrm{Hb}-\mathrm{O}_{2}$ affinity may provide better maintenance of $\mathrm{O}_{2}$ delivery and utilization in humans. Therefore, the purpose of this review is to highlight the potential advantages and disadvantages of high $\mathrm{Hb}-\mathrm{O}_{2}$ affinity in humans during hypoxia through examination of cardiovascular and respiratory adjustments at rest and during exercise.

To address the central question of this review, we examine available studies reporting cardiovascular or respiratory adjustments to hypoxia at rest or during exercise in humans with genetic mutations resulting in high $\mathrm{Hb}-\mathrm{O}_{2}$ affinity. To avoid confounding factors that may alter cardiovascular and respiratory responses, we excluded studies in which these individuals have recently undergone venesection. Studies fitting these criteria can be found in Table 1, including participant characteristics and experimental design. To clearly denote the "severity" of hypoxia within the discussion, we define low altitude as $<2500 \mathrm{~m}$, high altitude as $>2500 \mathrm{~m}$, and extreme altitude as $>7000 \mathrm{~m}$.

\section{FOUNDATIONAL CONCEPTS}

Hemoglobin-oxygen affinity is largely determined by the structure of hemoglobin and modulated by a variety of factors within the vasculature [temperature, $\mathrm{pH}, \mathrm{CO}_{2}, 2,3$ diphosphoglycerate (2,3-DPG), organic phosphates, chloride ions $\left(\mathrm{Cl}^{-}\right)$, etc.] (Mairbaurl et al., 1993). The relationship between the partial pressure of $\mathrm{O}_{2}\left(\mathrm{P}_{\mathrm{O}_{2}}\right)$ and $\mathrm{O}_{2}$ saturation can be described by the $\mathrm{O}_{2}$ dissociation curve (Figure 1). One common metric to quantify $\mathrm{Hb}-\mathrm{O}_{2}$ affinity is $\mathrm{P}_{50}$, defined as the $\mathrm{P}_{\mathrm{O}_{2}}$ at which $50 \%$ of hemoglobin is saturated with $\mathrm{O}_{2}$. A lower $\mathrm{P}_{50}$ corresponds to a higher $\mathrm{Hb}-\mathrm{O}_{2}$ binding affinity or a "left-shifted" $\mathrm{O}_{2}$ dissociation curve. On the other hand, a higher $\mathrm{P}_{50}$ corresponds to a lower $\mathrm{Hb}-\mathrm{O}_{2}$ binding affinity and a "right-shifted" $\mathrm{O}_{2}$ dissociation curve. In addition to $\mathrm{P}_{50}$, the Hill coefficient is often used to describe the curvature of the $\mathrm{O}_{2}$ dissociation curve (Endrenyi et al., 1975; Piiper, 1992; Riggs, 1998). However, describing the $\mathrm{O}_{2}$ dissociation curve with the $\mathrm{P}_{50}$ and the Hill coefficient presents some limitations. Experimentally, the $\mathrm{P}_{50}$ and Hill coefficient are commonly determined using in vitro standardized environmental conditions $\left[\mathrm{pH} \sim 7.4\right.$, partial pressure of $\mathrm{CO}_{2}\left(\mathrm{P}_{\mathrm{CO}_{2}}\right) \sim 40 \mathrm{mmHg}$, and temperature $\sim 37^{\circ} \mathrm{C}$, which does not account for transient changes in the in vivo modulation of $\mathrm{Hb}-\mathrm{O}_{2}$ affinity during circulatory transit (Braumann et al., 1982). Therefore, there is not "one" $\mathrm{O}_{2}$ dissociation curve because the binding affinity and cooperativity of hemoglobin vary throughout the vasculature. Nevertheless, standardized measurements of $\mathrm{P}_{50}$ and the Hill coefficient allow general inter-individual comparisons of $\mathrm{Hb}-\mathrm{O}_{2}$ affinity, but do not account for in vivo modulation of $\mathrm{Hb}$ $\mathrm{O}_{2}$ affinity.

Changes in $\mathrm{Hb}-\mathrm{O}_{2}$ affinity throughout the vasculature optimize both $\mathrm{O}_{2}$ loading in the lungs and $\mathrm{O}_{2}$ off-loading to peripheral tissue. For example, byproducts of metabolism (increased temperature, increased $\mathrm{CO}_{2}$, and lower $\mathrm{pH}$ ) contribute to a localized decrease in $\mathrm{Hb}-\mathrm{O}_{2}$ affinity in exercising muscle, thereby promoting $\mathrm{O}_{2}$ off-loading and utilization (Böning et al., 1975). Furthermore, a lower temperature and increased $\mathrm{pH}$ within the lung result in a localized increase in $\mathrm{Hb}-\mathrm{O}_{2}$ affinity and improved $\mathrm{O}_{2}$ loading (Mairbäurl, 2013). Alternatively, long-term regulation of modulatory factors or alterations in the structure of hemoglobin can lead to systemic wide changes in $\mathrm{Hb}-\mathrm{O}_{2}$ affinity. For instance, hypoxia increases 2,3-DPG concentration (due to increased glycolytic activity) in red blood cells contributing to a systemic decrease of $\mathrm{Hb}-\mathrm{O}_{2}$ affinity (Lenfant et al., 1968). Standard teaching supports that a decrease in $\mathrm{Hb}-\mathrm{O}_{2}$ affinity facilitates $\mathrm{O}_{2}$ off-loading during hypoxia (Hall et al., 1936; Aste-Salazar and Hurtado, 1944). Yet, the systemic decrease in $\mathrm{Hb}-\mathrm{O}_{2}$ affinity would compromise $\mathrm{O}_{2}$ loading in the lung, particularly when $\mathrm{O}_{2}$ availability is limited during hypoxia. At higher altitudes, a decrease in $\mathrm{Hb}-\mathrm{O}_{2}$ affinity would be even more disadvantageous and further compromised $\mathrm{O}_{2}$ loading would likely impede peripheral $\mathrm{O}_{2}$ delivery. Conversely, an increase in $\mathrm{Hb}-\mathrm{O}_{2}$ affinity during hypoxia promotes $\mathrm{O}_{2}$ loading within the lungs and mitigates reductions in arterial $\mathrm{O}_{2}$ saturation (Eaton et al., 1974; Yalcin and Cabrales, 2012). In addition, the advantages conferred by increased $\mathrm{Hb}-\mathrm{O}_{2}$ affinity are augmented at higher altitudes, outweighing potential limitations in $\mathrm{O}_{2}$ offloading (Eaton et al., 1974). Therefore, homeostatic maintenance of $\mathrm{O}_{2}$ delivery and utilization during hypoxia is contingent on the balance between $\mathrm{O}_{2}$ loading in the lungs and $\mathrm{O}_{2}$ off-loading in the periphery, both of which are largely determined by the $\mathrm{Hb}$ $\mathrm{O}_{2}$ affinity. Additional discussion of hemoglobin structure and the regulation of $\mathrm{Hb}-\mathrm{O}_{2}$ affinity is presented below (see section "Hemoglobin-Oxygen Affinity").

\section{Hemoglobin-Oxygen Affinity}

Hemoglobin is a tetramer consisting of two $\alpha$-subunits and two $\beta$-subunits (Coates, 1975). Each subunit contains a heme group that is capable of reversibly binding $\mathrm{O}_{2}$ (Perutz, 1963). When hemoglobin is fully saturated four $\mathrm{O}_{2}$ molecules are bound independently to each of the four 
TABLE 1 | Studies examining cardiorespiratory adjustments during normoxia or hypoxia in humans with high $\mathrm{Hb}_{2} \mathrm{O}_{2}$ affinity.

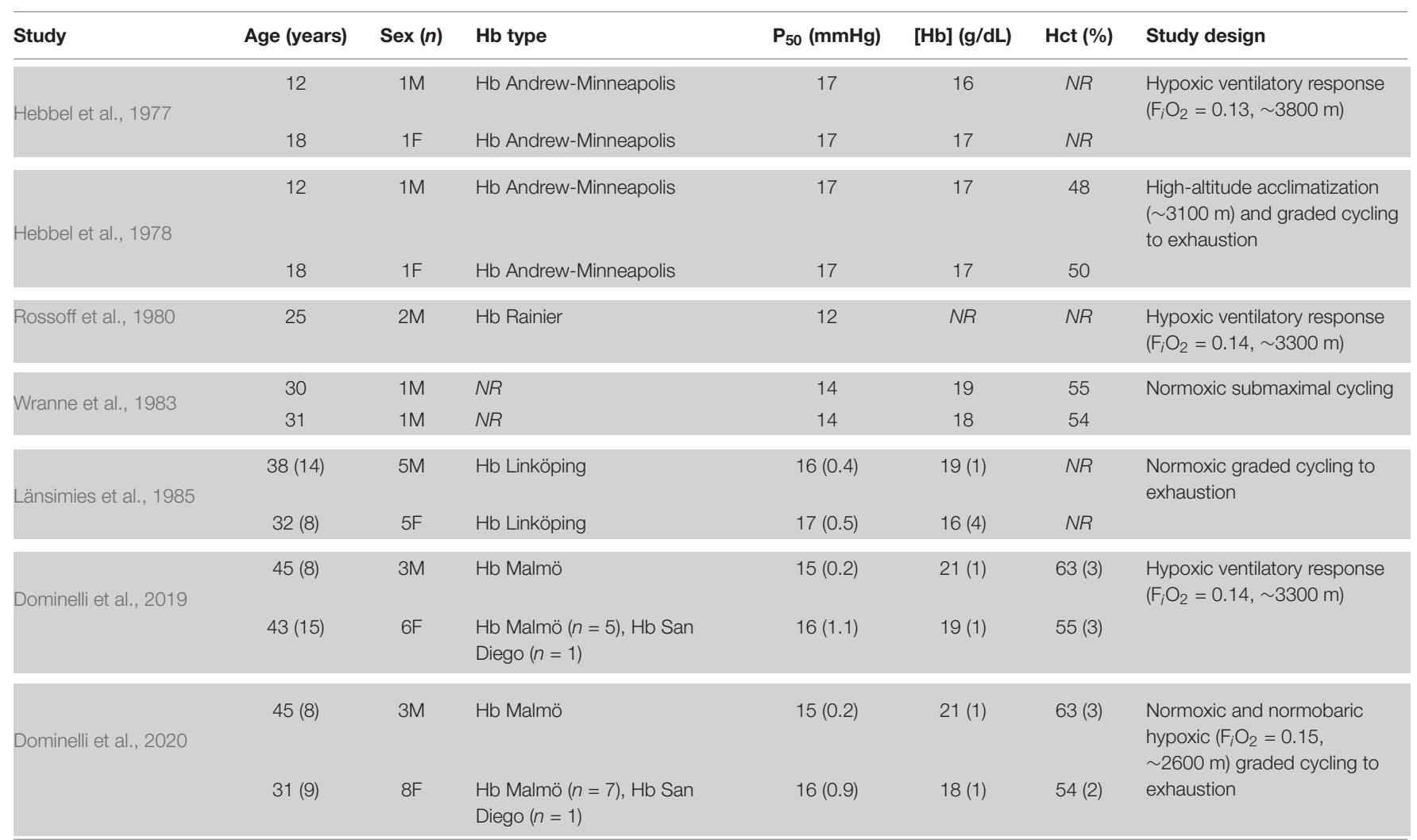

The fraction of inspired $\mathrm{O}_{2}$ and associated elevation are provided under study design.

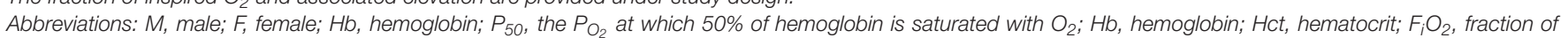
inspired $\mathrm{O}_{2} ; \mathrm{NR}$, not reported. Numbers within parentheses throughout the table indicate standard deviations.

subunits of the hemoglobin molecule. Hemoglobin undergoes a conformational shift with each $\mathrm{O}_{2}$ molecule that binds, existing in a $\mathrm{T}$ (tense) state when deoxygenated and a $\mathrm{R}$ (relaxed) state when oxygenated, commonly described by a two-state model (Monod et al., 1965). As each individual subunit becomes oxygenated, a conformational shift further increases binding affinity for $\mathrm{O}_{2}$ (Mihailescu and Russu, 2001). This cooperativity in $\mathrm{O}_{2}$ binding to hemoglobin gives rise to the sigmoidal shape of the $\mathrm{O}_{2}$ dissociation curve (Figure 1).

Hemoglobin is subject to allosteric regulation by multiple ligands. Most notably, higher concentrations of $\mathrm{H}^{+}$and $\mathrm{CO}_{2}$ reduce $\mathrm{Hb}-\mathrm{O}_{2}$ affinity (Riggs, 1960; Ho and Russu, 1987). This $\mathrm{pH}$ dependent change of $\mathrm{Hb}-\mathrm{O}_{2}$ affinity is termed the Bohr effect (Bohr et al., 1904). Hb-O 2 affinity is also reduced at higher temperatures (Weber and Campbell, 2011). For example, an increase of temperature from 37 to $40^{\circ} \mathrm{C}$ raises $\mathrm{P}_{50}$ from normal values of $\sim 27$ to $30 \mathrm{mmHg}$ (Hlastala et al., 1977). Additionally, the magnitude of the Bohr effect is greater at higher temperatures, further promoting $\mathrm{O}_{2}$ off-loading from hemoglobin (Hlastala et al., 1977). The cooperative effect of a more acidic environment along with higher temperatures, as occurs during rigorous exercise, significantly reduces $\mathrm{Hb}-\mathrm{O}_{2}$ affinity such that $\mathrm{P}_{50}$ may increase up to $\sim 40 \mathrm{mmHg}$ within the vasculature (Thomson et al., 1974). In the case of severe respiratory alkalosis, a fivefold increase in minute ventilation may reduce arterial $\mathrm{P}_{\mathrm{CO}_{2}}$ from normal values of $\sim 40 \mathrm{mmHg}$ to as low as $7 \mathrm{mmHg}$ and blood pH may exceed 7.7 (Houston et al., 1987; West, 2006). At extreme altitudes, in vivo $\mathrm{P}_{50}$ may be reduced to less than $20 \mathrm{mmHg}$ due to changes in blood $\mathrm{P}_{\mathrm{CO}_{2}}$ and pH (West, 1984; Winslow et al., 1984).

The erythrocytic concentrations of 2,3-DPG and $\mathrm{Cl}^{-}$are associated with more long-term modulation of $\mathrm{Hb}-\mathrm{O}_{2}$ affinity. In effect, 2,3-DPG and $\mathrm{Cl}^{-}$bind to deoxygenated hemoglobin and stabilize the T state, reducing $\mathrm{Hb}-\mathrm{O}_{2}$ affinity (Benesch et al., 1967; Brewer, 1974). 2,3-DPG reduces $\mathrm{Hb}-\mathrm{O}_{2}$ affinity and increases the cooperativity of hemoglobin, which "right-shifts" the $\mathrm{O}_{2}$ dissociation curve and steepens the slope (Tyuma et al., 1971). In addition, an influx of $\mathrm{Cl}^{-}$into the red blood cell, coupled to the outward transport of bicarbonate, reduces $\mathrm{Hb}-\mathrm{O}_{2}$ affinity (Wieth et al., 1982; Perutz et al., 1994; Prange et al., 2001). These ligands elicit independent effects on $\mathrm{Hb}-\mathrm{O}_{2}$ affinity, and complex in vivo interactions between ligands give rise to the physiological $\mathrm{P}_{50}$ of hemoglobin. For example, 2,3-DPG and $\mathrm{Cl}^{-}$compete for binding to hemoglobin and the effect 2,3DPG on $\mathrm{Hb}-\mathrm{O}_{2}$ affinity disappears at high concentrations of $\mathrm{Cl}^{-}$ (Imai, 1982). In addition, the Bohr effect is more pronounced at greater concentrations of 2,3-DPG (Bauer, 1969). The interested reader may consult other sources for more detailed discussions on modulation of $\mathrm{Hb}-\mathrm{O}_{2}$ affinity (Antonini and Brunori, 1970; Mairbaurl and Weber, 2012). 
The severity and duration of hypoxia is an important factor when considering in vivo modulation of $\mathrm{Hb}-\mathrm{O}_{2}$ affinity in humans. During sojourns to altitudes of $\sim 4500 \mathrm{~m}$ or less, humans demonstrate a reduced $\mathrm{Hb}-\mathrm{O}_{2}$ affinity due to elevated production of 2,3-DPG (Lenfant et al., 1968). At these elevations, hyperventilation reduces blood $\mathrm{P}_{\mathrm{CO}_{2}}$ and potentially results in respiratory alkalosis (Dempsey and Forster, 1982). However, renal compensation leads to the excretion of excess bicarbonate and conservation of $\mathrm{H}^{+}$, normalizing blood $\mathrm{pH}$ to sea-level values after a few days at high altitude (Goldfarb-Rumyantzev and Alper, 2014; Bird et al., 2021). At higher elevations (4500-5400 m), hyperventilation becomes so pronounced that renal compensation is insufficient and blood $\mathrm{pH}$ increases (West, 2006). The rise in blood $\mathrm{pH}$ increases $\mathrm{Hb}-\mathrm{O}_{2}$ affinity, counteracting the effects of an elevated 2,3-DPG production such that $\mathrm{P}_{50}$ approximates values observed at sea-level (Mairbaurl and Weber, 2012). As humans travel above $\sim 5400 \mathrm{~m}, \mathrm{Hb}-\mathrm{O}_{2}$ affinity increases as the respiratory alkalosis becomes more severe (West, 1984).

Contemporary studies suggest a potential role of hemoglobin found in cells other than erythrocytes such as alveolar epithelial cells, lung cells, and mesangial cells (Du et al., 2012; Saha et al., 2014). Within these non-erythrocytic cells, the production of hemoglobin appears to be upregulated in response to hypoxia (Cheung et al., 1997; Tezel et al., 2009; Grek et al., 2011), potentially serving as a "reservoir" for $\mathrm{O}_{2}$ (Saha et al., 2014). Therefore, a key area for future investigation is the relationship between non-erythroid hemoglobin production and hypoxia tolerance. However, there is currently minimal evidence to suggest that non-erythroid hemoglobin provides a functional impact on cardiovascular adjustments during hypoxia.

\section{Pharmacological Induction of High Hemoglobin-Oxygen Affinity}

Several pharmacological methods which transfuse 2,3-DPG depleted red blood cells into both animals and humans have allowed investigation into the role of high $\mathrm{Hb}-\mathrm{O}_{2}$ affinity in $\mathrm{O}_{2}$ transport (Riggs et al., 1973; Woodson et al., 1973; Wranne et al., 1974; Bakker et al., 1976; Malmberg et al., 1979; Woodson and Auerbach, 1982; Birchard and Tenney, 1991). However, methods used to achieve 2,3-DPG depletion often alter acidbase balance and total blood volume, potentially confounding the observed cardiorespiratory adjustments (Birchard and Tenney, 1991). More recent developments of pharmaceuticals that induce high $\mathrm{Hb}-\mathrm{O}_{2}$ affinity allow examination of altered $\mathrm{Hb}-\mathrm{O}_{2}$ affinity with fewer complications (Dufu et al., 2017; Kalfa et al., 2019; Stewart et al., 2020, 2021). For example, voxelotor binds allosterically to some, but not all hemoglobin and increases $\mathrm{Hb}-\mathrm{O}_{2}$ affinity. Hemoglobin modified with voxelotor exhibits a reduced Bohr effect compared to unmodified hemoglobin (Pochron et al., 2019), which may limit $\mathrm{O}_{2}$ offloading during instances where blood $\mathrm{pH}$ decreases such as rigorous exercise.

In general, allosteric modifiers allow for the manipulation of $\mathrm{Hb}-\mathrm{O}_{2}$ affinity with less perturbations in acid-base balance associated with 2,3-DPG depletion techniques. However, in

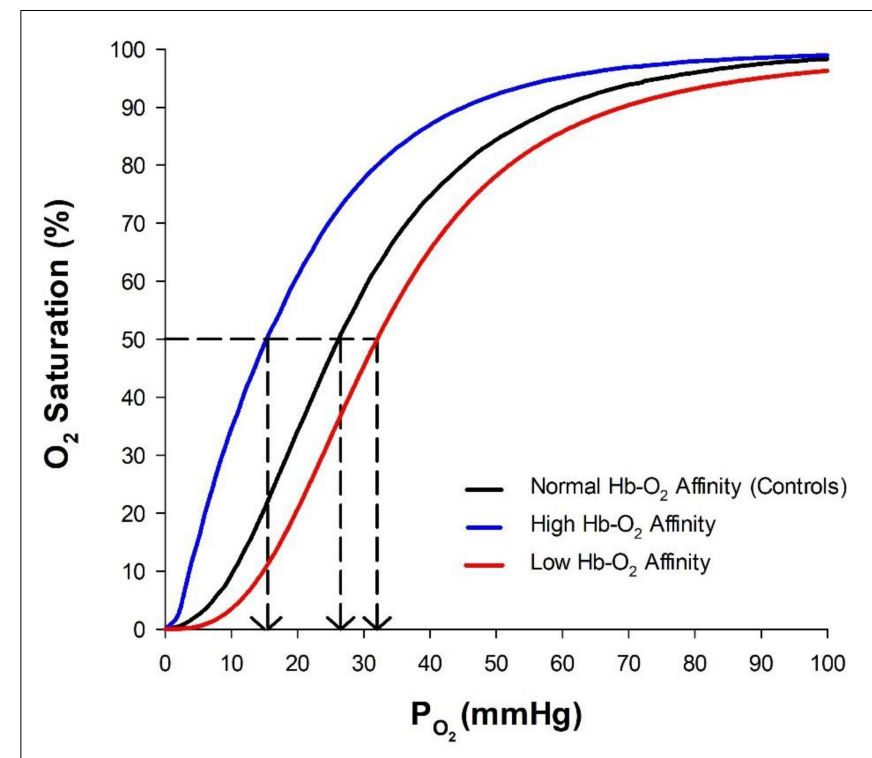

FIGURE 1 | Oxygen dissociation curve showing normal hemoglobin- $\mathrm{O}_{2}$ $\left(\mathrm{Hb}_{2} \mathrm{O}_{2}\right)$ affinity $\left(\mathrm{P}_{50} \sim 26 \mathrm{mmHg}\right)$, high $\mathrm{Hb}-\mathrm{O}_{2}$ affinity $\left(\mathrm{P}_{50} \sim 16 \mathrm{mmHg}\right)$, and low $\mathrm{Hb}-\mathrm{O}_{2}$ affinity $\left(\mathrm{P}_{50} \sim 32 \mathrm{mmHg}\right.$ ). The $\mathrm{P}_{50}$, denoted by the dashed lines, is defined as the $\mathrm{P}_{2}$ at which $50 \%$ of hemoglobin is saturated with $\mathrm{O}_{2}$.

healthy humans voxelotor induces only a modest decrease in $\mathrm{P}_{50}$ of $\sim 2 \mathrm{mmHg}$ (Stewart et al., 2020, 2021) compared to the greater range from 3 to $10 \mathrm{mmHg}$ obtained via 2,3DPG depletion (Gillette et al., 1974; Wranne et al., 1974). The ability to pharmacologically alter $\mathrm{Hb}-\mathrm{O}_{2}$ affinity in humans both acutely and chronically may provide additional insights on the context-dependent circumstances at which high $\mathrm{Hb}-\mathrm{O}_{2}$ affinity is advantageous (i.e., magnitude and duration of hypoxia).

\section{Humans With High Hemoglobin-Oxygen Affinity Hemoglobinopathies}

Currently, over 200 distinct mutations resulting in high $\mathrm{Hb}$ $\mathrm{O}_{2}$ affinity have been identified (Charache et al., 1966; Mangin, 2017). By definition, high $\mathrm{Hb}-\mathrm{O}_{2}$ affinity is characterized by a $\mathrm{P}_{50}$ less than $24 \mathrm{mmHg}$ (Figure 1; Rumi et al., 2009; Mangin, 2017). However, a majority of high $\mathrm{Hb}-\mathrm{O}_{2}$ affinity hemoglobinopathies examined are associated with $\mathrm{P}_{50}$ values ranging from 12 to $17 \mathrm{mmHg}$ (Table 1). Both the amino acid substitution and location at which the substitution occurs within the hemoglobin molecule may affect $\mathrm{Hb}-\mathrm{O}_{2}$ affinity, cooperativity, and response to modulatory ligands. Within the hemoglobin mutations represented in this review (Table 1), all exhibit reduced cooperativity and only $\mathrm{Hb}$ Andrew-Minneapolis demonstrates a reduced Bohr effect (Adamson et al., 1969; Boyer et al., 1972; Nute et al., 1974; Zak et al., 1974; Wranne et al., 1983; Berlin et al., 2009). Lower cooperativity gives rise to the unique shape of the standard $\mathrm{O}_{2}$ dissociation curve in humans with high $\mathrm{Hb}-\mathrm{O}_{2}$ affinity (Figure 1). However, the complex interactions between modulatory factors and subsequent effects on in vivo $\mathrm{Hb}-\mathrm{O}_{2}$ affinity have not been clearly elucidated in mutated hemoglobin molecules. 
Due to a lower $\mathrm{P}_{50}, \mathrm{O}_{2}$ off-loading is likely compromised in those with high $\mathrm{Hb}-\mathrm{O}_{2}$ affinity. Evidence for compromised $\mathrm{O}_{2}$ off-loading may be seen through compensatory increases in hematocrit resulting in a higher $\mathrm{O}_{2}$ carrying capacity per unit of blood (Charache et al., 1966; Mangin, 2017; Shepherd et al., 2019). It is thought that the kidneys sense a reduction of $\mathrm{O}_{2}$ off-loading and promote red blood cell production in response, functioning as a "critmeter" (Donnelly, 2001). In addition to an elevated hematocrit humans with high $\mathrm{Hb}-\mathrm{O}_{2}$ affinity likely develop skeletal muscle adaptations to compromised $\mathrm{O}_{2}$ offloading such as a greater percentage of non-oxidative (type II) muscle fibers than their counterparts with normal $\mathrm{Hb}-\mathrm{O}_{2}$ affinity (Wranne et al., 1983). Additionally, a greater accumulation of metabolic byproducts (e.g., lactate and $\mathrm{H}^{+}$) during highintensity exercise have been reported in humans with high $\mathrm{Hb}-\mathrm{O}_{2}$ affinity compared to those with normal $\mathrm{Hb}-\mathrm{O}_{2}$ affinity (Länsimies et al., 1985; Dominelli et al., 2020). Those with high $\mathrm{Hb}-\mathrm{O}_{2}$ affinity demonstrate a similar lactate accumulation at the end of exhaustive exercise during both normoxia and hypoxia, whereas controls demonstrate a reduced lactate accumulation during hypoxia compared to normoxia (Dominelli et al., 2020). A possible explanation for these observations may be that humans with high $\mathrm{Hb}-\mathrm{O}_{2}$ affinity obtain similar power outputs in normoxia and hypoxia and therefore demonstrate a similar metabolite accumulation between the two conditions; whereas those with normal $\mathrm{Hb}-\mathrm{O}_{2}$ affinity have a reduced power output and lower lactate concentrations during hypoxia compared to normoxia.

The observed differences in skeletal muscle fiber composition and utilization of metabolic pathways supporting exercise between humans with high $\mathrm{Hb}-\mathrm{O}_{2}$ affinity and humans with normal $\mathrm{Hb}-\mathrm{O}_{2}$ affinity may be due to differences in $\mathrm{O}_{2}$ offloading kinetics and tissue $\mathrm{P}_{\mathrm{O}_{2}}$ (Wranne et al., 1983). In general, many physiological compensatory responses coinciding with high $\mathrm{Hb}-\mathrm{O}_{2}$ affinity remain uncharacterized. Key areas for future investigation include adaptations to high $\mathrm{Hb}-\mathrm{O}_{2}$ affinity possibly affecting capillary density, blood flow distribution, and skeletal muscle aerobic capacity (Dempsey, 2020).

\section{HIGH HEMOGLOBIN-OXYGEN AFFINITY AND CARDIORESPIRATORY ADJUSTMENTS DURING HYPOXIA AT REST}

\section{Acute Hypoxia}

Brief periods of hypoxia require both cardiovascular and respiratory adjustments to maintain adequate $\mathrm{O}_{2}$ delivery (Rowell and Blackmon, 1987; Bärtsch and Saltin, 2008; Naeije, 2010). One crucial immediate adjustment in response to hypoxia is increased ventilation which raises alveolar ventilation, increases arterial $\mathrm{P}_{\mathrm{O}_{2}}$ and protects against arterial $\mathrm{O}_{2}$ desaturation (Otis et al., 1956; Dempsey and Forster, 1982). At a given alveolar $\mathrm{P}_{\mathrm{O}_{2}}$, humans with high $\mathrm{Hb}-\mathrm{O}_{2}$ affinity have similar minute ventilation compared to humans with normal $\mathrm{Hb}$ $\mathrm{O}_{2}$ affinity (Hebbel et al., 1977; Rossoff et al., 1980; Dominelli
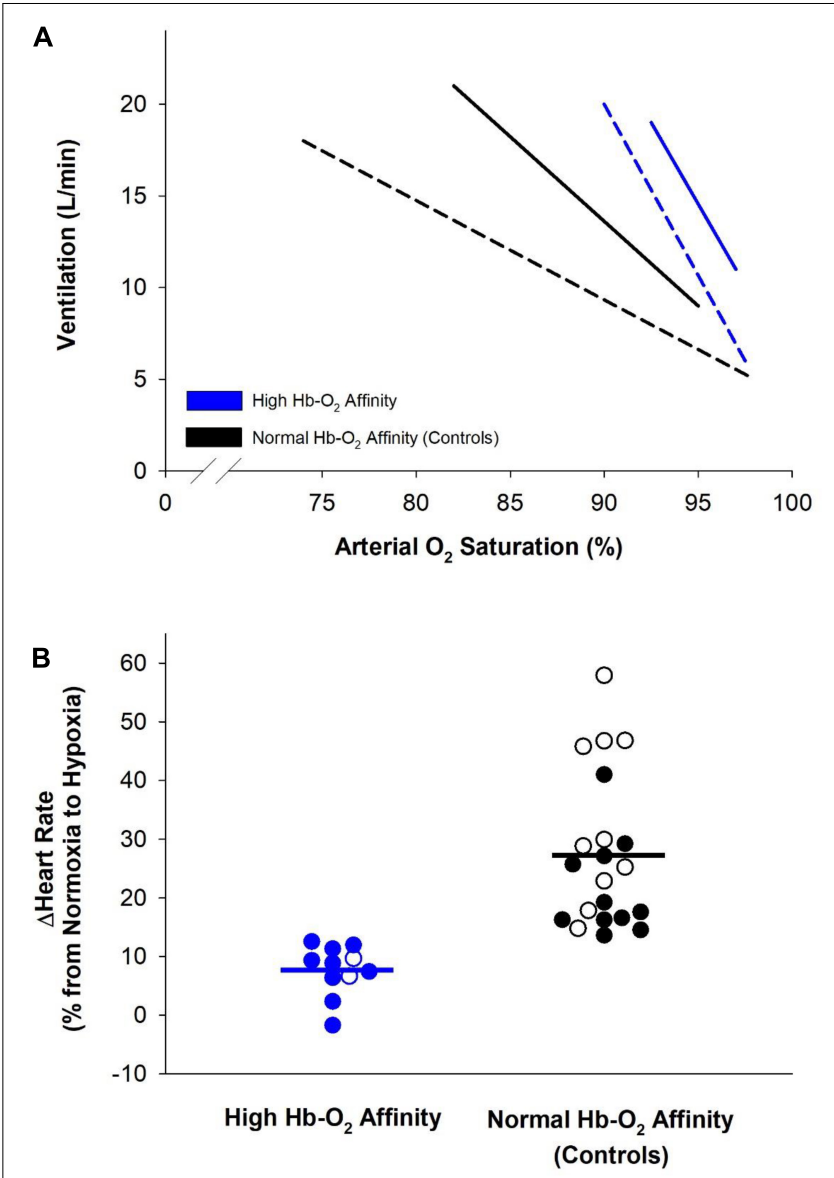

FIGURE 2 | Cardiorespiratory adjustments elicited during hypoxia by humans with high hemoglobin- $\mathrm{O}_{2}\left(\mathrm{Hb}-\mathrm{O}_{2}\right)$ affinity (blue lines and symbols) and controls with normal $\mathrm{Hb}-\mathrm{O}_{2}$ affinity (black lines and symbols). (A) Relationship of minute ventilation and arterial $\mathrm{O}_{2}$ saturation among humans with high $\mathrm{Hb}-\mathrm{O}_{2}$ affinity compared to normal $\mathrm{Hb}-\mathrm{O}_{2}$ affinity controls during progressive isocapnic hypoxia. Dashed lines represent data from Hebbel et al. (1977) where hypoxia was increased such that alveolar $\mathrm{P}_{\mathrm{O}_{2}}$ was lowered from 120 to $40 \mathrm{mmHg}$ over $\sim 5 \mathrm{~min}$ ( $n=2$ humans with high $\mathrm{Hb}_{2} \mathrm{O}_{2}$ affinity and $n=2$ humans with normal $\mathrm{Hb}-\mathrm{O}_{2}$ affinity). Solid lines represent data from Dominelli et al. (2019) where hypoxia was increased such that end-tidal $\mathrm{P}_{\mathrm{O}_{2}}$ was lowered from normal room-air values to $50 \mathrm{mmHg}$ over $\sim 12 \mathrm{~min}(n=9$ humans with high $\mathrm{Hb}-\mathrm{O}_{2}$ affinity and $n=12$ humans with normal $\mathrm{Hb}_{2} \mathrm{O}_{2}$ affinity). (B) Percentage increase in heart rate during progression of normoxia to hypoxia among humans with high $\mathrm{Hb}^{-\mathrm{O}_{2}}$ affinity compared to normal $\mathrm{Hb}-\mathrm{O}_{2}$ affinity controls. Open symbols represent data from $\mathrm{Heb}$ bel et al. (1977) where heart rate was compared at an alveolar $\mathrm{P}_{\mathrm{O}_{2}}$ of 100 and $40 \mathrm{mmHg}\left(n=2\right.$ humans with high $\mathrm{Hb}_{2} \mathrm{O}_{2}$ affinity and $n=10$ humans with normal $\mathrm{Hb}-\mathrm{O}_{2}$ affinity). Filled symbols represent data from Dominelli et al. (2019) where heart rate was compared at normoxia and at an end-tidal $\mathrm{P}_{2}$ of $50 \mathrm{mmHg}\left(n=9\right.$ humans with high $\mathrm{Hb}^{-\mathrm{O}_{2}}$ affinity and $n=12$ humans with normal $\mathrm{Hb}_{2} \mathrm{O}_{2}$ affinity). Solid bars represent the average change in heart rate in both groups.

et al., 2019). Yet, due to the left-shifted nature of their oxygen dissociation curve, those with high $\mathrm{Hb}-\mathrm{O}_{2}$ affinity have a higher arterial $\mathrm{O}_{2}$ saturation at a given alveolar $\mathrm{P}_{\mathrm{O}_{2}}$ (Figure 2A; Hebbel et al., 1977; Rossoff et al., 1980; Dominelli et al., 2019).

In addition to increased ventilation, hypoxia is associated with increased cardiac output, primarily through an elevated 
heart rate (Brown and Grocott, 2013; Siebenmann and Lundby, 2015). As arterial $\mathrm{O}_{2}$ saturation decreases during hypoxia, cardiac output increases and peripheral arterioles dilate to match $\mathrm{O}_{2}$ delivery and demand (Ekblom et al., 1975; Phillips et al., 1988). These observations suggest that the change in heart rate during acute hypoxia is closely linked to systemic $\mathrm{O}_{2}$ delivery (Casey and Joyner, 2011; Joyner and Casey, 2014; Siebenmann and Lundby, 2015). During acute hypoxia, humans with high Hb$\mathrm{O}_{2}$ affinity display a lesser increase in heart rate, and presumably cardiac output, likely due to better maintained arterial $\mathrm{O}_{2}$ content (Figure 2B; Hebbel et al., 1977; Dominelli et al., 2019). Since arterial $\mathrm{O}_{2}$ saturation remains fairly constant in humans with high $\mathrm{Hb}-\mathrm{O}_{2}$ affinity during modest reductions of $\mathrm{P}_{\mathrm{O}_{2}}$, as occurs at moderately high altitude, arterial $\mathrm{O}_{2}$ content is better maintained and heart rate increases to a lesser extent compared to those with normal $\mathrm{Hb}-\mathrm{O}_{2}$ affinity.

Peripheral chemosensors located at both the carotid and aortic bodies respond to acute changes in arterial $\mathrm{P}_{\mathrm{O}_{2}}$ and $\mathrm{P}_{\mathrm{CO}_{2}}$, such as during normobaric and hypobaric hypoxia (Lahiri and Forster, 2003). Stimulation of peripheral chemosensors during hypoxic exposure causes an increase in minute ventilation and sympathetic activity in an attempt to maintain $\mathrm{O}_{2}$ homeostasis (Powell et al., 1998; Bernardi et al., 2001; Fletcher, 2001). Examination of humans with high $\mathrm{Hb}-\mathrm{O}_{2}$ affinity provides support for low $\mathrm{P}_{\mathrm{O}_{2}}$ being a strong stimulus in the hypoxic ventilatory response, rather than arterial $\mathrm{O}_{2}$ saturation or content (Hebbel et al., 1977; Rossoff et al., 1980; Dominelli et al., 2019). Some evidence suggests that aortic chemosensors sense changes in arterial $\mathrm{O}_{2}$ content and heart rate is adjusted accordingly (Lugliani et al., 1971; Wasserman, 1978; Lahiri et al., 1980, 1981). Therefore, the lower heart rate during hypoxia among humans with high $\mathrm{Hb}-\mathrm{O}_{2}$ affinity compared to controls may be caused by decreased sensory stimulus of the aortic chemosensors (Dominelli et al., 2019). However, the mechanistic stimulation of the peripheral chemosensors requires that $\mathrm{O}_{2}$ be dissociated from hemoglobin to be sensed (Lopez-Barneo et al., 2001). Therefore, the relationship between $\mathrm{O}_{2}$ content and $\mathrm{P}_{\mathrm{O}_{2}}$ sensed at the carotid chemosensors remains unclear and contention exists regarding mechanisms of $\mathrm{O}_{2}$ sensing and regulation of systemic blood flow (Ward, 2008). Detailed discussions into the mechanism of $\mathrm{O}_{2}$ sensing are provided elsewhere (Lopez-Barneo et al., 2001; Kumar and Prabhakar, 2012).

The observed relationship between ventilation and arterial $\mathrm{O}_{2}$ saturation may present a disadvantage to humans with high $\mathrm{Hb}$ $\mathrm{O}_{2}$ affinity during acute hypoxic exposure. Since the stimulus for ventilation is closely linked to arterial $\mathrm{P}_{\mathrm{O}_{2}}$ and not arterial $\mathrm{O}_{2}$ saturation during brief periods of hypoxia (Biscoe, 1971; Guz, 1975; Weil and Zwillich, 1976), humans with high Hb$\mathrm{O}_{2}$ affinity have an excessive ventilatory response despite only a modest drop in arterial $\mathrm{O}_{2}$ saturation and delivery (Figure 2A). Excessive ventilation increases $\mathrm{O}_{2}$ consumption by respiratory muscles (Cherniack, 1959; Robertson et al., 1977). Although accounting for a small percentage of total $\mathrm{O}_{2}$ consumption during rest, respiratory muscle $\mathrm{O}_{2}$ demand increases during hyperventilation or exercise (Aaron et al., 1992; Coast et al., 1993; Dominelli et al., 2015). Thus, during exercise, there are increased and competitive demands for $\mathrm{O}_{2}$ in metabolically active tissue including both exercising muscle and respiratory muscle (Harms et al., 2000; Sheel et al., 2001; Romer and Polkey, 2008; Dominelli et al., 2017). This competition for blood flow between respiratory and exercising muscle limits exercise tolerance at higher and extreme altitudes and is often referred to as "respiratory steal" (Pugh et al., 1964; Schoene, 2001; Helfer et al., 2016). The physiological consequences of "respiratory steal" are likely exacerbated at more extreme altitudes as hyperventilation, and thus metabolic demand of respiratory muscle, becomes more pronounced. Therefore, the excessive hyperventilation during acute hypoxic exposure may be disadvantageous for humans with high $\mathrm{Hb}-\mathrm{O}_{2}$ affinity due to increased $\mathrm{O}_{2}$ consumption by respiratory muscles with minimal improvement in arterial $\mathrm{O}_{2}$ saturation.

\section{Chronic Hypoxia}

In addition to acute hypoxic exposure, the benefits of high $\mathrm{Hb}-\mathrm{O}_{2}$ affinity have been observed through examination of cardiorespiratory adjustments during 10-days of residing at high altitude (Leadville, Colorado, $\sim 3100$ m elevation) (Hebbel et al., 1978). Two humans with high $\mathrm{Hb}-\mathrm{O}_{2}$ affinity and two of their siblings with normal $\mathrm{Hb}-\mathrm{O}_{2}$ affinity were examined during the acclimatization period. Changes in arterial 2,3-DPG concentration and $\mathrm{pH}$ were similar during the stay at high altitude in both sets of siblings. However, peak and average heart rate during acclimatization were lower in the siblings with high $\mathrm{Hb}-\mathrm{O}_{2}$ affinity. During hypoxia, impaired $\mathrm{O}_{2}$ delivery to the kidneys prompts erythropoietin production (Donnelly, 2001; Nangaku and Eckardt, 2007; Haase, 2013). Erythropoietin stimulates red blood cell production and leads to a subsequent increase in $\mathrm{O}_{2}$ carrying capacity to compensate for impaired $\mathrm{O}_{2}$ delivery (Erslev, 1991; Jelkmann, 2011). Humans with high Hb$\mathrm{O}_{2}$ affinity showed smaller increases in erythropoietin production when residing at high altitude (Hebbel et al., 1978). A lesser erythropoietin production during high-altitude acclimatization suggests that $\mathrm{O}_{2}$ delivery is better preserved among humans with high $\mathrm{Hb}-\mathrm{O}_{2}$ affinity. Similarly, Hall et al. (1936) showed that mammals native to high altitude display a reduced erythropoietic response during travel from low altitude to high altitude. Combined, these findings suggest that lessened cardiovascular adjustments are needed to maintain adequate $\mathrm{O}_{2}$ delivery during high-altitude acclimatization in humans with high $\mathrm{Hb}-\mathrm{O}_{2}$ affinity compared to those with normal $\mathrm{Hb}-\mathrm{O}_{2}$ affinity.

Marked physiological compensations are required to maintain homeostasis during sojourn to extreme altitudes (West, 2006). $\mathrm{Hb}-\mathrm{O}_{2}$ affinity increases at altitudes greater than $\sim 5400 \mathrm{~m}$ due to severe respiratory alkalosis with insufficient renal compensations (see section "Hemoglobin-Oxygen Affinity"). During ascent to the summit of Mt. Everest, $\sim 8100 \mathrm{~m}$, climbers had a reduction in $\mathrm{P}_{50}$ from $\sim 26 \mathrm{mmHg}$ to less than $\sim 20 \mathrm{mmHg}$ (West, 1984). A more recent study examining blood oxygenation of four climbers reported arterial saturations ranging from 34 to $70 \%$ at the summit of Everest (Grocott et al., 2009). Without an increase of $\mathrm{Hb}-\mathrm{O}_{2}$ affinity due to respiratory alkalosis it is likely that humans would not be able to reach the summit without supplemental $\mathrm{O}_{2}$. 
As extreme altitude challenges the ability to transport $\mathrm{O}_{2}$ from atmospheric air to tissue, the modulation of $\mathrm{Hb}-\mathrm{O}_{2}$ affinity is crucial to maintain adequate $\mathrm{O}_{2}$ consumption. Enhanced $\mathrm{O}_{2}$ loading in the lungs due to high $\mathrm{Hb}-\mathrm{O}_{2}$ affinity is even more advantageous at extreme altitude than at high altitude, where ambient $\mathrm{P}_{\mathrm{O}_{2}}$ can fall to as low as $40 \mathrm{mmHg}$, outweighing potential limitations in $\mathrm{O}_{2}$ off-loading (Eaton et al., 1974). The ventilatory response during hypoxia is similar between humans with genetic mutations leading to high $\mathrm{Hb}-\mathrm{O}_{2}$ affinity and those with normal $\mathrm{Hb}-\mathrm{O}_{2}$ affinity (Hebbel et al., 1977; Rossoff et al., 1980; Dominelli et al., 2019). Under the circumstances of extreme altitude, humans with high $\mathrm{Hb}-\mathrm{O}_{2}$ affinity may develop respiratory alkalosis to a similar degree as observed in humans with normal $\mathrm{Hb}-\mathrm{O}_{2}$ affinity (West, 1984; Grocott et al., 2009). In addition, some genetic hemoglobin mutations demonstrate a preserved Bohr effect, such that $\mathrm{Hb}-\mathrm{O}_{2}$ affinity would decrease during respiratory alkalosis by a similar magnitude compared to non-mutated hemoglobin (Adamson et al., 1969; Boyer et al., 1972; Nute et al., 1974; Wranne et al., 1983; Berlin et al., 2009). A physiological consequence of respiratory alkalosis would be further left-shifted $\mathrm{O}_{2}$ dissociation curve adding additional protection against arterial desaturation. Therefore, humans with genetic modifications resulting in high $\mathrm{Hb}-\mathrm{O}_{2}$ affinity and a preserved Bohr effect may ascend to extreme altitudes with fewer physiological complications (i.e., Acute mountain sickness, high-altitude cerebral edema, and impaired cognitive function) compared to sojourners with normal $\mathrm{Hb}-\mathrm{O}_{2}$ affinity. However, to our knowledge no humans with genetic high $\mathrm{Hb}-\mathrm{O}_{2}$ affinity have been examined at altitudes greater than $\sim 3100 \mathrm{~m}$ and the proposed physiologic responses to higher and extreme altitudes are theoretical.

Groups of indigenous humans who have resided at high altitude for many generations display genotypic and phenotypic adaptations to the hypoxic environment (Beall, 2007, 2014; Moore, 2017; Tymko et al., 2019; Storz, 2021). Recent evidence has suggested an adaptive increase of $\mathrm{Hb}-\mathrm{O}_{2}$ affinity among high altitude natives of the Qinghai-Tibetan Plateau (>3500 m) compared to sea-level residents (Simonson et al., 2014; Li et al., 2018). However, others have reported that some highaltitude populations [Nepalese $(>3800 \mathrm{~m})$, Peruvian $(>4500 \mathrm{~m})$, and Qinghai-Tibetan $(>3500 \mathrm{~m})$ natives] do not show this adaptive increase in $\mathrm{Hb}-\mathrm{O}_{2}$ affinity (Samaja et al., 1979; Winslow et al., 1981; Tashi et al., 2014). Additional studies may improve understanding of changes in $\mathrm{Hb}-\mathrm{O}_{2}$ affinity observed among high-altitude natives and molecular mechanisms underlying such adaptation.

The Qinghai-Tibetan natives had a $\mathrm{P}_{50} \sim 2 \mathrm{mmHg}$ lower than the sea-level residents ( 24.5 vs. $26.2 \mathrm{mmHg}$, respectively) (Simonson et al., 2014). However, the high-altitude natives did not display improvements in pulmonary gas exchange or peak exercise capacity during hypoxia compared to the sea-level residents, suggesting no clear benefit of high $\mathrm{Hb}-\mathrm{O}_{2}$ affinity in the population examined. These findings, contradictory to those observed in humans with genetic mutations resulting in high $\mathrm{Hb}-\mathrm{O}_{2}$ affinity, could be explained by differences in the magnitude of $\mathrm{P}_{50}$. The high-altitude natives studied had a $\mathrm{P}_{50}$ of $\sim 25 \mathrm{mmHg}$, in contrast to values ranging from 12 to $17 \mathrm{mmHg}$ observed in humans with genetic mutations resulting in high $\mathrm{Hb}-\mathrm{O}_{2}$ affinity (Table 1 ). Therefore, the $\mathrm{P}_{50}$ observed in the highaltitude native population is probably not low enough to warrant significant alterations in pulmonary gas exchange, $\mathrm{O}_{2}$ extraction, and exercise capacity during hypoxia. In addition, adaptations of high-altitude populations, which affect multiple steps within the $\mathrm{O}_{2}$ transport cascade (Beall, 2007), may confound our ability to clearly dissociate the role of increased $\mathrm{Hb}-\mathrm{O}_{2}$ affinity in humans native to high altitude.

\section{HIGH HEMOGLOBIN-OXYGEN AFFINITY AND CARDIORESPIRATORY ADJUSTMENTS DURING EXERCISE}

\section{Maximal Oxygen Consumption During Normoxia}

Studies examining the effects of pharmacologically induced high $\mathrm{Hb}-\mathrm{O}_{2}$ affinity on $\mathrm{O}_{2}$ consumption during normoxia have provided discordant results in both humans and animals (Riggs et al., 1973; Woodson et al., 1973; Wranne et al., 1974; Valeri et al., 1975; Yhap et al., 1975; Bakker et al., 1976; Malmberg et al., 1979; Ross and Hlastala, 1981; Woodson and Auerbach, 1982; Stewart et al., 2020, 2021). Recently, Stewart et al. (2021) showed that pharmaceutical induction of high $\mathrm{Hb}-\mathrm{O}_{2}$ affinity (only $\sim 2 \mathrm{mmHg}$ decrease in $\left.\mathrm{P}_{50}\right)$ using voxelotor reduced normoxic maximal $\mathrm{O}_{2}$ consumption $\left(\dot{\mathrm{V}}_{2 \max }\right)$ in humans. The decrement in normoxic $\dot{\mathrm{VO}}_{2 \text { max }}$ observed by Stewart et al. (2021) could be due to both an increase in $\mathrm{Hb}-\mathrm{O}_{2}$ affinity and a reduced Bohr effect: the transient reduction of $\mathrm{Hb}-\mathrm{O}_{2}$ affinity with decreasing pH (Pochron et al., 2019). A reduced Bohr effect in exercising muscle would further compromise $\mathrm{O}_{2}$ off-loading, particularly during periods of high metabolic demand (Mairbäurl, 2013). Conversely, some mathematical models suggest that normoxic $\dot{\mathrm{VO}}_{2 \text { max }}$ is relatively insensitive to modest increases in $\mathrm{Hb}-\mathrm{O}_{2}$ affinity despite limitations in $\mathrm{O}_{2}$ off-loading (Wagner, 1997; Shepherd et al., 2019).

In corroboration with results found through mathematical modeling, humans with high $\mathrm{Hb}-\mathrm{O}_{2}$ affinity show no difference in normoxic $\dot{\mathrm{VO}}_{2 \max }$ values compared to similar age, sexmatched controls with normal $\mathrm{Hb}-\mathrm{O}_{2}$ affinity (Länsimies et al., 1985; Dominelli et al., 2020). However, there is evidence for altered metabolic processes among humans with high $\mathrm{Hb}-\mathrm{O}_{2}$ affinity compared to controls during exercise testing. During cycling exercise in normoxia, humans with high $\mathrm{Hb}-\mathrm{O}_{2}$ affinity may have greater reliance on anaerobic metabolism during heavy to maximal exercise, as evidenced by lower blood $\mathrm{pH}$ and pronounced lactate production compared to controls (Wranne et al., 1983; Länsimies et al., 1985; Dominelli et al., 2020). In addition, humans with high $\mathrm{Hb}-\mathrm{O}_{2}$ affinity seem to display a worsened exercise efficiency during cycling, i.e., higher $\mathrm{O}_{2}$ consumption for a given power output (Dominelli et al., 2020). Theoretically, compromised $\mathrm{O}_{2}$ off-loading due to high $\mathrm{Hb}-\mathrm{O}_{2}$ affinity may give rise to the greater reliance on anaerobic metabolism, which contributes to the worsened exercise efficiency observed (Dominelli et al., 2020). In brief, 


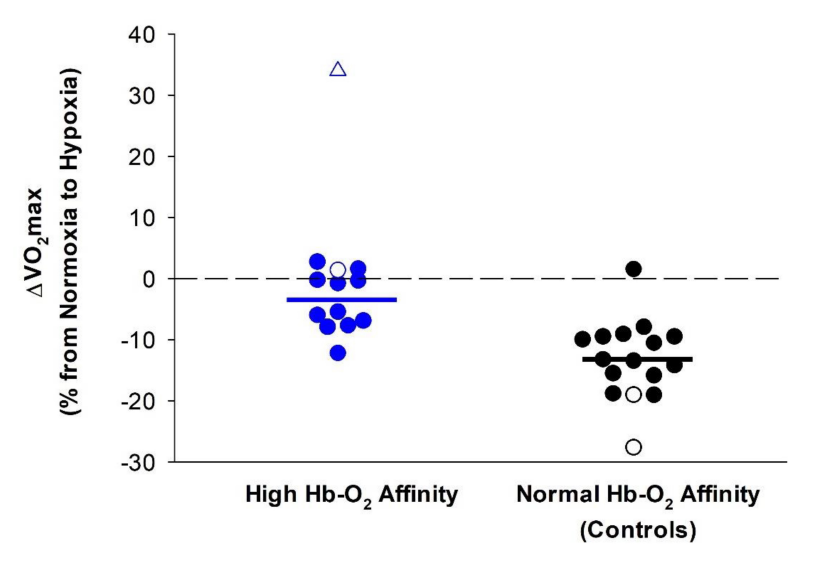

FIGURE 3 | Difference in $\dot{\mathrm{V}}_{2 \text { max }}$ between normoxia and hypoxia in humans with high $\mathrm{Hb}_{2} \mathrm{O}_{2}$ affinity (blue symbols) ( $-4 \pm 5 \%$ without outlier) compared to normal $\mathrm{Hb}-\mathrm{O}_{2}$ affinity controls (black symbols) $(-13 \pm 6 \%)$. Open symbols represent data from Hebbel et al. (1978). The open triangle represents an outlier not included in the calculation of the mean. Closed symbols represent data from Dominelli et al. (2020). Solid bars represent the average change in $\dot{\mathrm{V}}_{2 \text { max }}$ in both groups not including the outlier with high $\mathrm{Hb}-\mathrm{O}_{2}$ affinity. The dashed line provides a reference for no change.

current evidence indicates that humans with high $\mathrm{Hb}-\mathrm{O}_{2}$ affinity have similar normoxic $\dot{\mathrm{V}}{ }_{2 \text { max }}$ values despite altered metabolic processes during high-intensity exercise.

Little is known about the relationship between high $\mathrm{Hb}-\mathrm{O}_{2}$ affinity and compensatory mechanisms that facilitate adequate $\mathrm{O}_{2}$ extraction. Wranne et al. (1983) demonstrated that the arterial-venous $\mathrm{O}_{2}$ extraction was abnormally low during exercise in humans with high $\mathrm{Hb}-\mathrm{O}_{2}$ affinity, suggesting that $\mathrm{O}_{2}$ offloading may be compromised within muscle during whole-body exercise. However, humans with high $\mathrm{Hb}-\mathrm{O}_{2}$ affinity had a $\sim 25 \%$ greater $\mathrm{O}_{2}$ carrying capacity than those with normal $\mathrm{Hb}-\mathrm{O}_{2}$ affinity, likely compensating for the diminished arterial-venous $\mathrm{O}_{2}$ extraction both at rest and during exercise. The potential benefits of high $\mathrm{Hb}-\mathrm{O}_{2}$ affinity are likely contingent on the capacity to extract $\mathrm{O}_{2}$ from blood (Wearing et al., 2021). The capacity of $\mathrm{O}_{2}$ off-loading and diffusion to the mitochondria are crucial to maximize $\mathrm{O}_{2}$ utilization in cases of high $\mathrm{Hb}-\mathrm{O}_{2}$ affinity, especially during peak whole-body exercise. Therefore, future research should focus on the relationship between high $\mathrm{Hb}-\mathrm{O}_{2}$ affinity and compensatory mechanisms which facilitate adequate $\mathrm{O}_{2}$ extraction within peripheral tissue such as alterations in the microvascular architecture, flow of the red blood cells through the microvasculature, and the diffusion gradients driving $\mathrm{O}_{2}$ to the mitochondria.

\section{Maximal Oxygen Consumption During Hypoxia}

Maximal $\mathrm{O}_{2}$ consumption in humans decreases with increasing severity of hypoxia (Faulkner et al., 1968; Grover, 1970; Lawler et al., 1988; Ferretti et al., 1997; Wehrlin and Hallén, 2006; Wagner, 2010; West, 2010). However, humans with high Hb$\mathrm{O}_{2}$ affinity are better able to maintain $\dot{\mathrm{VO}}_{2}$ max during hypoxia compared to those with normal $\mathrm{Hb}-\mathrm{O}_{2}$ affinity (Figure 3).
As previously described, Hebbel and colleagues examined four siblings, two with high $\mathrm{Hb}-\mathrm{O}_{2}$ affinity and two with normal $\mathrm{Hb}-\mathrm{O}_{2}$ affinity, during 10 days of high-altitude acclimatization (Leadville, Colorado, $\sim 3100 \mathrm{~m}$ elevation). At high altitude $\dot{\mathrm{V}} \mathrm{O}_{2 \max }$ decreased by $\sim 28$ and 19\% compared to sea-level values in the two siblings with normal $\mathrm{Hb}-\mathrm{O}_{2}$ affinity (Hebbel et al., 1978). On the other hand, the two siblings with high $\mathrm{Hb}-\mathrm{O}_{2}$ affinity did not demonstrate a reduction in $\dot{\mathrm{VO}}_{2 \max }$ at high altitude compared to low altitude (Hebbel et al., 1978).

Similarly, experiments using acute normobaric hypoxia showed that humans with high $\mathrm{Hb}-\mathrm{O}_{2}$ affinity had better maintained $\mathrm{VO}_{2 \max }$ during hypoxia compared to humans with normal $\mathrm{Hb}-\mathrm{O}_{2}$ affinity (Dominelli et al., 2020). In addition, peak power output during cycling exercise was better preserved in those with high $\mathrm{Hb}-\mathrm{O}_{2}$ affinity (Dominelli et al., 2020). At both high altitude and normobaric hypoxia, there was no difference in maximal heart rate during exercise in humans with high $\mathrm{Hb}-\mathrm{O}_{2}$ affinity compared to those with normal $\mathrm{Hb}-\mathrm{O}_{2}$ affinity (Hebbel et al., 1978; Dominelli et al., 2020). Previous studies indicate that an increase in blood viscosity associated with an elevated hematocrit, common in humans with chronic high $\mathrm{Hb}$ $\mathrm{O}_{2}$ affinity, may limit blood flow and maximal cardiac output in humans (Richardson and Guyton, 1959; Schumacker et al., 1985; Ç1nar et al., 1999). On the contrary, some studies suggest that systemic blood flow at rest and during exercise within animals is not reduced at a hematocrit of $\sim 50-60 \%$ (Gaehtgens et al., 1979; Schumacker et al., 1985; Lindenfeld et al., 2005). However, hematocrits greater than $60 \%$ likely result in a substantially elevated blood viscosity such that systemic blood flow is restricted (Weisse et al., 1964; Gaehtgens et al., 1979; Schumacker et al., 1985). Therefore, it is unclear whether cardiac output and systemic blood flow is limited among humans with high $\mathrm{Hb}-\mathrm{O}_{2}$ affinity where hematocrit often ranges from $\sim 55$ to $65 \%$.

The reduction of $\mathrm{V}_{2 \max }$ during hypoxia is directly related to the degree of arterial desaturation (Hughes et al., 1968; Calbet et al., 2003a). As such, a higher arterial $\mathrm{O}_{2}$ saturation in humans with high $\mathrm{Hb}-\mathrm{O}_{2}$ affinity for a given level of hypoxia likely contributes to the preservation of hypoxic $\dot{\mathrm{VO}}_{2 \text { max }}$ (Figure 3). In humans with normal $\mathrm{Hb}-\mathrm{O}_{2}$ affinity at high altitude, hypoxic $\dot{\mathrm{VO}}_{2 \max }$ is less than values measured at sea-level and hypoxic $\dot{\mathrm{VO}}_{2 \text { max }}$ either remains the same or progressively increases during acclimatization (Saltin et al., 1968; Calbet et al., 2003 b). Despite acclimatization, hypoxic $\dot{\mathrm{VO}}_{2 \max }$ does not reach values previously measured at sea-level (Calbet et al., 2003b). In contrast, humans with high $\mathrm{Hb}-\mathrm{O}_{2}$ affinity have a better maintained hypoxic $\dot{\mathrm{VO}}_{2 \max }$ upon transition to high altitude, but it is unknown how humans with high $\mathrm{Hb}-\mathrm{O}_{2}$ affinity may acclimatize to high altitude and subsequent effects on hypoxic $\mathrm{V}_{2 \max }$.

\section{CONCLUSION}

High $\mathrm{Hb}-\mathrm{O}_{2}$ affinity has been identified as a potentially advantageous adaptation to high altitude in several animal species. From a cardiorespiratory perspective, we suggest that high $\mathrm{Hb}-\mathrm{O}_{2}$ affinity is advantageous for humans when exposed 
to hypoxic environments both at rest and during exercise. During hypoxia, humans with high $\mathrm{Hb}-\mathrm{O}_{2}$ affinity exhibit lessened increases in heart rate, reduced erythropoietin production, and higher arterial $\mathrm{O}_{2}$ saturation at rest compared to those with normal $\mathrm{Hb}-\mathrm{O}_{2}$ affinity. In addition, $\mathrm{V}_{2 \max }$ and work capacity are better maintained during hypoxia compared to normoxia in humans with high $\mathrm{Hb}-\mathrm{O}_{2}$ affinity. The advantages associated with high $\mathrm{Hb}-\mathrm{O}_{2}$ affinity are likely potentiated as the degree of hypoxia becomes more severe. In addition, high $\mathrm{Hb}-\mathrm{O}_{2}$ affinity confers physiological disadvantages at less severe magnitudes of hypoxia such as reduced $\mathrm{O}_{2}$ off-loading and unwarranted hyperventilation when arterial $\mathrm{O}_{2}$ saturation is fairly well-preserved. However, current understanding on the effects of high $\mathrm{Hb}-\mathrm{O}_{2}$ affinity during hypoxia is largely limited to normobaric hypoxia. Future research warrants the investigation into the influence of high $\mathrm{Hb}-\mathrm{O}_{2}$ affinity during both short- and long-term periods of high-altitude acclimatization. In addition, longterm adaptations to pharmaceutically induced high $\mathrm{Hb}-\mathrm{O}_{2}$ affinity in humans remains largely unexamined. Regardless, the influence of high $\mathrm{Hb}-\mathrm{O}_{2}$ affinity on cardiorespiratory adjustments to environmental hypoxia is of key interest in

\section{REFERENCES}

Aaron, E. A., Seow, K. C., Johnson, B. D., and Dempsey, J. A. (1992). Oxygen cost of exercise hyperpnea: implications for performance. J. Appl. Physiol. 72, 1818-1825. doi: 10.1152/jappl.1992.72.5.1818

Adamson, J. W., Parer, J. T., Stamatoyannopoulos, G., and Heinenberg, S. (1969). Erythrocytosis associated with hemoglobin Rainier: oxygen equilibria and marrow regulation. J. Clin. Invest. 48, 1376-1386. doi: 10.1172/JCI106103

Antonini, E., and Brunori, M. (1970). Hemoglobin. Annu. Rev. Biochem. 39, 977-1042. doi: 10.1146/annurev.bi.39.070170.004553

Aste-Salazar, H., and Hurtado, A. (1944). The affinity of hemoglobin for oxygen at sea level and at high altitudes. Am. J. Physiol. Legacy Content 142, 733-743. doi: 10.1152/ajplegacy.1944.142.5.733

Bakker, J. C., Gortmaker, G. C., and Offerijns, F. G. J. (1976). The influence of the position of the oxygen dissociation curve on oxygen-dependent functions of the isolated perfused rat liver. Pflugers Arch. 366, 45-52. doi: 10.1007/BF0106 3456

Bartels, H., Hilpert, P., Barbey, K., Betke, K., Riegel, K., Lang, E. M., et al. (1963). Respiratory functions of blood of the yak, llama, camel, Dybowski deer, and African elephant. Am. J. Physiol. Legacy Content. 205, 331-336. doi: 10.1152/ ajplegacy.1963.205.2.331

Bärtsch, P., and Saltin, B. (2008). General introduction to altitude adaptation and mountain sickness: altitude adaptation and mountain sickness. Scand. J. Med. Sci. Sports 18, 1-10. doi: 10.1111/j.1600-0838.2008.00827.x

Bauer, C. H. (1969). Antagonistic influence of CO2 and 2,3 diphosphoglycerate on the Bohr effect of human haemoglobin. Life Sci. 8, 1041-1046. doi: 10.1016/ 0024-3205(69)90455-X

Beall, C. M. (2007). Two routes to functional adaptation: tibetan and Andean highaltitude natives. Proc. Natl. Acad. Sci. U.S.A. 104, 8655-8660. doi: 10.1073/pnas. 0701985104

Beall, C. M. (2014). Adaptation to high altitude: phenotypes and genotypes. Annu. Rev. Anthropol. 43, 251-272. doi: 10.1146/annurev-anthro-102313-030000

Benesch, R., Benesch, R. E., and Smith, M. (1967). The effect of organic phosphates from the human erythrocyte on the allosteric properties of hemoglobin. J. Biol. Chem. 26, 162-167. doi: 10.1016/0006-291X(67)90228-8

Berlin, G., Wranne, B., and Jeppsson, J.-O. (2009). Hb Linköping ( $\beta 36$ Pro $\rightarrow$ Thr): a new high oxygen affinity hemoglobin variant found in two families of Finnish origin. Eur. J. Haematol. 39, 452-456. doi: 10.1111/j.1600-0609.1987.tb01455.x human adaptation to environmental hypoxia, particularly during bouts of exercise.

\section{AUTHOR CONTRIBUTIONS}

MJ and CW conceived the concept for this review. KW, JS, and CW drafted the manuscript. PD, SB, JS, SK, and MJ provided critical revision of the manuscript for important intellectual content. All authors approved the final version of the manuscript.

\section{FUNDING}

This project was supported by the National Institutes of Health R-35-HL139854 and the Mayo Foundation (to MJ). KW was supported by NIH-T32-HL105355-10 and the Mayo Clinic Graduate School of Biomedical Sciences. SB was supported by NIH-K01-HL148144-01A1. SK was supported by a Natural Sciences and Engineering Research Council of Canada Postdoctoral Fellowship PDF-532926-2019. JS was supported by NIH-F32-HL-154320-01.

Bernardi, L., Passino, C., Serebrovskaya, Z., Serebrovskaya, T., and Appenzeller, O. (2001). Respiratory and cardiovascular adaptations to progressive hypoxia. Eur. Heart 22, 879-886. doi: 10.1053/euhj.2000.2466

Birchard, G. F., and Tenney, S. M. (1991). Relationship between blood-oxygen affinity and blood volume. Respir. Physiol. 83, 365-373. doi: 10.1016/00345687(91)90055-N

Bird, J. D., Leacy, J. K., Foster, G. E., Rickards, C. A., Wilson, R. J. A., O’Halloran, K. D., et al. (2021). Time course and magnitude of ventilatory and renal acidbase acclimatization following rapid ascent to and residence at $3,800 \mathrm{~m}$ over nine days. J. Appl. Physiol. 130, 1705-1715. doi: 10.1152/japplphysiol.00973. 2020

Biscoe, T. J. (1971). Carotid body: structure and function. Physiol. Rev. 51, 437-480. doi: 10.1152/physrev.1971.51.3.437

Bohr, C., Hasselbalch, K., and Krogh, A. (1904). Ueber einen in biologischer Beziehung wichtigen Einfluss, den die Kohlensäurespannung des Blutes auf dessen Sauerstoffbindung übt. Skand. Arch. Physiol. 16, 402-412. doi: 10.1111/ j.1748-1716.1904.tb01382.x

Böning, D., Schweigart, U., Tibes, U., and Hemmer, B. (1975). Influences of exercise and endurance training on the oxygen dissociation curve of blood under in vivo and in vitro conditions. Eur. J. Appl. Physiol. 34, 1-10. doi: 10.1007/BF0099 9910

Boyer, S. H., Charache, S., Fairbanks, V. F., Maldonado, J. E., Noyes, A., and Gayle, E. E. (1972). Hemoglobin malmö $\beta$-97 (FG-4) Histidine $\rightarrow$ Glutamine: a cause of polycythemia. J. Clin. Invest. 51, 666-676. doi: 10.1172/JCI106855

Braumann, K. M., Boning, D., and Trost, F. (1982). Bohr effect and slope of the oxygen dissociation curve after physical training. J. Appl. Physiol. 52, 1524-1529. doi: 10.1152/jappl.1982.52.6.1524

Brewer, G. J. (1974). 2,3-DPG and erythrocyte oxygen affinity. Annu. Rev. Med. 25, 29-38. doi: 10.1146/annurev.me.25.020174.000333

Brown, J. P., and Grocott, M. P. (2013). Humans at altitude: physiology and pathophysiology. Continuing Educ. Anaesthesia Crit. Care Pain 13, 17-22. doi: 10.1093/bjaceaccp/mks047

Calbet, J. A. L., Boushel, R., Rådegran, G., Søndergaard, H., Wagner, P. D., and Saltin, B. (2003a). Determinants of maximal oxygen uptake in severe acute hypoxia. Am. J. Physiol. Regul. Integr. Comp. Physiol. 284, R291-R303. doi: 10.1152/ajpregu.00155.2002

Calbet, J. A. L., Boushel, R., Rådegran, G., Søndergaard, H., Wagner, P. D., and Saltin, B. (2003b). Why is $\mathrm{VO}_{2} \max$ after altitude acclimatization still reduced 
despite normalization of arterial $\mathrm{O}_{2}$ content? Am. J. Physiol. Regul. Integr. Comp. Physiol. 284, R304-R316. doi: 10.1152/ajpregu.00156.2002

Casey, D. P., and Joyner, M. J. (2011). Local control of skeletal muscle blood flow during exercise: influence of available oxygen. J. Appl. Physiol. 111, 1527-1538. doi: 10.1152/japplphysiol.00895.2011

Charache, S., Weatherall, D. J., and Clegg, J. B. (1966). Polycythemia associated with a hemoglobinopathy. J. Clin. Invest. 45, 813-822. doi: 10.1172/JCI105397

Cherniack, R. M. (1959). The oxygen consumption and efficiency of the repsiratory muscles in health and emphysema. J. Clin. Invest. 38, 494-499. doi: 10.1172/ JCI103826

Cheung, P., Panning, B., and Smiley, J. R. (1997). Herpes simplex virus immediateearly proteins ICP0 and ICP4 activate the endogenous human alpha-globin gene in nonerythroid cells. J. Virol. 71, 1784-1793. doi: 10.1128/JVI.71.3.17841793.199

Çınar, Y., Demir, G., Paç, M., and Cınar, A. B. (1999). Effect of hematocrit on blood pressure via hyperviscosity. Am. J. Hypertens. 12, 739-743. doi: 10.1016/S08957061(99)00011-4

Coast, J. R., Rasmussen, S. A., Krause, K. M., O’Kroy, J. A., Loy, R. A., and Rhodes, J. (1993). Ventilatory work and oxygen consumption during exercise and hyperventilation. J. Appl. Physiol. 74, 793-798. doi: 10.1152/jappl.1993.74. 2.793

Coates, M. L. (1975). Hemoglobin function in the vertebrates: an evolutionary model. J. Mol. Evol. 6, 285-307. doi: 10.1007/BF01794636

Dempsey, J. A. (2020). With haemoglobin as with politics - should we shift right or left? J. Physiol. 598, 1419-1420. doi: 10.1113/JP279555

Dempsey, J. A., and Forster, H. V. (1982). Mediation of ventilatory adaptations. Physiol. Rev. 62, 262-346. doi: 10.1152/physrev.1982.62.1.262

Dominelli, P. B., Archiza, B., Ramsook, A. H., Mitchell, R. A., Peters, C. M., Molgat-Seon, Y., et al. (2017). Effects of respiratory muscle work on respiratory and locomotor blood flow during exercise. Exp. Physiol. 102, 1535-1547. doi: 10.1113/EP086566

Dominelli, P. B., Baker, S. E., Wiggins, C. C., Stewart, G. M., Sajgalik, P., Shepherd, J. R. A., et al. (2019). Dissociating the effects of oxygen pressure and content on the control of breathing and acute hypoxic response. J. Appl. Physiol. 127, 1622-1631. doi: 10.1152/japplphysiol.00569.2019

Dominelli, P. B., Render, J. N., Molgat-Seon, Y., Foster, G. E., Romer, L. M., and Sheel, A. W. (2015). Oxygen cost of exercise hyperpnoea is greater in women compared with men. J. Physiol. 593, 1965-1979. doi: 10.1113/jphysiol.2014. 285965

Dominelli, P. B., Wiggins, C. C., Baker, S. E., Shepherd, J. R. A., Roberts, S. K., Roy, T. K., et al. (2020). Influence of high affinity haemoglobin on the response to normoxic and hypoxic exercise. J. Physiol. 598, 1475-1490. doi: 10.1113/ JP279161

Donnelly, S. (2001). Why is erythropoietin made in the kidney? The kidney functions as a critmeter. Am. J. Kidney Dis. 38, 415-425. doi: 10.1053/ajkd.2001. 26111

Du, R., Winarsih, I., Ho, B., and Ding, J. L. (2012). Lipid-free apolipoprotein A-I exerts an antioxidative role against cell-free hemoglobin. Am. J. Clin. Exp. Immunol. 1, 33-48.

Dufu, K., Yalcin, O., Ao-ieong, E. S. Y., Hutchaleelala, A., Xu, Q., Li, Z., et al. (2017). GBT1118, a potent allosteric modifier of hemoglobin $\mathrm{O}_{2}$ affinity, increases tolerance to severe hypoxia in mice. Am. J. Physiol. Heart Circ. 313, H381-H391. doi: 10.1152/ajpheart.00772.2016

Eaton, J. W., Skelton, T. D., and Berger, E. (1974). Survival at extreme altitude: protective effect of increased hemoglobin-oxygen affinity. Science 183, 743-744. doi: $10.1126 /$ science. 183.4126 .743

Ekblom, B., Huot, R., Stein, E. M., and Thorstensson, A. T. (1975). Effect of changes in arterial oxygen content on circulation and physical performance. J. Appl. Physiol. 39, 71-75. doi: 10.1152/jappl.1975.39.1.71

Endrenyi, L., Kwong, F. H. F., and Fajszi, C. (1975). Evaluation of hill slopes and hill coefficients when the saturation binding or velocity is not known. Eur. J. Biochem. 51, 317-328. doi: 10.1111/j.1432-1033.1975.tb03931.x

Erslev, A. J. (1991). Erythropoietin. N. Engl. J. Med. 324, 1339-1344. doi: 10.1056/ NEJM199105093241907

Faulkner, J. A., Kollias, J., Favour, C. B., Buskirk, E. R., and Balke, B. (1968). Maximum aerobic capacity and running performance at altitude. J. Appl. Physiol. 24, 685-691. doi: 10.1152/jappl.1968.24.5.685
Ferretti, G., Moia, C., Thomet, J. M., and Kayser, B. (1997). The decrease of maximal oxygen consumption during hypoxia in man: a mirror image of the oxygen equilibrium curve. J. Physiol. 498, 231-237. doi: 10.1113/jphysiol.1997. sp021854

Fletcher, E. C. (2001). Invited Review: physiological consequences of intermittent hypoxia: systemic blood pressure. J. Appl. Physiol. 90, 1600-1605. doi: 10.1152/ jappl.2001.90.4.1600

Gaehtgens, P., Kreutz, F., and Albrecht, K. H. (1979). Optimal hematocrit for canine skeletal muscle during rhythmic isotonic exercise. Eur. J. Appl. Physiol. Occup. Physiol. 41, 27-39. doi: 10.1007/BF00424466

Gillette, P. N., Peterson, C. M., Lu, Y. S., and Cerami, A. (1974). Sodium cyanate as a potential treatment for sickle-cell disease. N. Engl. J. Med. 290, 654-660. doi: 10.1056/NEJM197403212901204

Goldfarb-Rumyantzev, A. S., and Alper, S. L. (2014). Short-term responses of the kidney to high altitude in mountain climbers. Nephrol. Dial. Transplant. 29, 497-506. doi: 10.1093/ndt/gft051

Grek, C. L., Newton, D. A., Spyropoulos, D. D., and Baatz, J. E. (2011). Hypoxia Up-regulates expression of hemoglobin in alveolar epithelial cells. Am. J. Respir. Cell Mol. Biol. 44, 439-447. doi: 10.1165/rcmb.2009-0307OC

Grocott, M. P. W., Levett, D. Z. H., and Windsor, J. (2009). Arterial blood gases and oxygen content in climbers on mount everest. N. Eng. J. Med. 360, 140-149. doi: 10.1056/NEJMoa0801581

Grover, R. (1970). Limitation of aerobic working capacity at high altitude. Hypoxia High Altitude Heart 5, 11-16. doi: 10.1159/000387629

Guz, A. (1975). Regulation of respiration in man. Annu. Rev. Physiol. 37, 303-323. doi: 10.1146/annurev.ph.37.030175.001511

Haase, V. H. (2013). Mechanisms of hypoxia responses in renal tissue. J. Am. Soc. Nephrol. 24, 537-541. doi: 10.1681/ASN.2012080855

Hall, F. G., Dill, D. B., and Barron, E. S. G. (1936). Comparative physiology in high altitudes. J. Cellular Comparat. Physiol. 8, 301-313. doi: 10.1002/jcp. 1030080302

Harms, C. A., Wetter, T. J., St. Croix, C. M., Pegelow, D. F., and Dempsey, J. A. (2000). Effects of respiratory muscle work on exercise performance. J. Appl. Physiol. 89, 131-138. doi: 10.1152/jappl.2000.89.1.131

Hebbel, R. P., Eaton, J. W., Kronenberg, R. S., Zanjani, E. D., Moore, L. G., and Berger, E. M. (1978). Human llamas: adaptation to altitude in subjects with high hemoglobin oxygen affinity. J. Clin. Invest. 62, 593-600. doi: 10.1172/JCI10 9165

Hebbel, R. P., Kronenberg, R. S., and Eaton, J. W. (1977). Hypoxic ventilatory response in subjects with normal and high oxygen affinity hemoglobins. J. Clin. Invest. 60, 1211-1215. doi: 10.1172/JCI108874

Helfer, S., Quackenbush, J., Fletcher, M., and Pendergast, D. R. (2016). Respiratory muscle training and exercise endurance at altitude. Aerosp. Med. Hum. Perform. 87, 704-711. doi: 10.3357/AMHP.4405.2016

Hlastala, M. P., Woodson, R. D., and Wranne, B. (1977). Influence of temperature on hemoglobin-ligand interaction in whole blood. J. Appl. Physiol. 43, 545-550. doi: 10.1152/jappl.1977.43.3.545

Ho, C., and Russu, I. M. (1987). How much do we know about the Bohr effect of hemoglobin? Biochemistry 26, 6299-6305. doi: 10.1021/bi00394a001

Houston, C. S., Sutton, J. R., Cymerman, A., and Reeves, J. T. (1987). Operation Everest II: man at extreme altitude. J. Appl. Physiol. 63, 877-882. doi: 10.1152/ jappl.1987.63.2.877

Hughes, R. L., Clode, M., Edwards, R. H., Goodwin, T. J., and Jones, N. L. (1968). Effect of inspired $\mathrm{O} 2$ on cardiopulmonary and metabolic responses to exercise in man. J. Appl. Physiol. 24, 336-347. doi: 10.1152/jappl.1968.24.3.336

Humpeler, E., and Amor, H. (1973). Sex differences in the oxygen affinity of hemoglobin. Pflugers Arch. 343, 151-156. doi: 10.1007/BF00585710

Imai, K. (1982). Allosteric Effects in Haemoglobin. Cambridge: Cambridge University Press.

Jelkmann, W. (2011). Regulation of erythropoietin production: erythropoietin production. J. Physiol. 589, 1251-1258. doi: 10.1113/jphysiol.2010.195057

Jensen, F. B. (2004). Red blood cell pH, the Bohr effect, and other oxygenationlinked phenomena in blood O2 and CO2 transport. Acta Physiol. Scand. 182, 215-227. doi: 10.1111/j.1365-201X.2004.01361.x

Joyner, M. J., and Casey, D. P. (2014). Muscle blood flow, hypoxia, and hypoperfusion. J. Appl. Physiol. 116, 852-857. doi: 10.1152/japplphysiol.00620. 2013 
Kalfa, T. A., Kuypers, F. A., Telen, M. J., Malik, P., Konstantinidis, D. G., Estepp, J. H., et al. (2019). Phase 1 Single (SAD) and multiple ascending dose (MAD) studies of the safety, tolerability, pharmacokinetics (PK) and pharmacodynamics (PD) of FT-4202, an allosteric activator of pyruvate Kinase$\mathrm{R}$, in healthy and sickle cell disease subjects. Blood 134, 616-616. doi: 10.1182/ blood-2019-121889

Kumar, P., and Prabhakar, N. R. (2012). Peripheral chemoreceptors: function and plasticity of the carotid body. Compr. Physiol. 2, 141-219. doi: 10.1002/cphy. c100069

Lahiri, S., and Forster, R. E. (2003). CO2/H+ sensing: peripheral and central chemoreception. Int. J. Biochem. Cell Biol. 35, 1413-1435. doi: 10.1016/S13572725(03)00050-5

Lahiri, S., Mulligan, E., Nishino, T., Mokashi, A., and Davies, R. O. (1981). Relative responses of aortic body and carotid body chemoreceptors to carboxyhemoglobinemia. J. Appl. Physiol. 50, 580-586. doi: 10.1152/jappl.1981. 50.3.580

Lahiri, S., Nishino, T., Mokashi, A., and Mulligan, E. (1980). Relative responses of aortic body and carotid body chemoreceptors to hypotension. J. Appl. Physiol. 48, 781-788. doi: 10.1152/jappl.1980.48.5.781

Länsimies, E., Hyödynmaa, S., Lahtinen, R., Mahlamäki, E., Palomäki, P., and Rautiainen, M. (1985). Exercise capacity in subjects with high oxygen affinity. Clin. Physiol. 5, 69-73. doi: 10.1111/j.1475-097X.1985.tb00604.x

Lawler, J., Powers, S. K., and Thompson, D. (1988). Linear relationship between VO2max and VO2max decrement during exposure to acute hypoxia. J. Appl. Physiol. 64, 1486-1492. doi: 10.1152/jappl.1988.64.4.1486

Lenfant, C., and Sullivan, K. (1971). Adaptation to high altitude. N. Engl. J. Med. 284, 1298-1309. doi: 10.1056/NEJM197106102842305

Lenfant, C., Torrance, J., English, E., Finch, C. A., Reynafarje, C., Ramos, J., et al. (1968). Effect of altitude on oxygen binding by hemoglobin and on organic phosphate levels. J. Clin. Invest. 47, 2652-2656. doi: 10.1172/JCI105948

Li, C., Li, X., Liu, J., Fan, X., You, G., Zhao, L., et al. (2018). Investigation of the differences between the Tibetan and Han populations in the hemoglobinoxygen affinity of red blood cells and in the adaptation to high-altitude environments. Hematology 23, 309-313. doi: 10.1080/10245332.2017.1396046

Lindenfeld, J., Weil, J. V., Travis, V. L., and Horwitz, L. D. (2005). Regulation of oxygen delivery during induced polycythemia in exercising dogs. Am. J. Physiol. Heart Circ. 289, H1821-H1825. doi: 10.1152/ajpheart.01016.2004

Lopez-Barneo, J., Pardal, R., and Ortega-Sáenz, P. (2001). Cellular mechanism of oxygen sensing. Annu. Rev. Physiol. 63, 259-287. doi: 10.1146/annurev.physiol. 63.1.259

Lugliani, R., Whipp, B. J., Seard, C., and Wasserman, K. (1971). Effect of bilateral carotid-body resection on ventilatory control at rest and during exercise in man. N. Engl. J. Med. 285, 1105-1111. doi: 10.1056/NEJM197111112852002

Mairbäurl, H. (2013). Red blood cells in sports: effects of exercise and training on oxygen supply by red blood cells. Front. Physiol. 4:332. doi: 10.3389/fphys.2013. 00332

Mairbaurl, H., Oelz, O., and Bartsch, P. (1993). Interactions between Hb, Mg, DPG, ATP, and $\mathrm{Cl}$ determine the change in $\mathrm{Hb}-\mathrm{O} 2$ affinity at high altitude. J. Appl. Physiol. 74, 40-48. doi: 10.1152/jappl.1993.74.1.40

Mairbaurl, H., and Weber, R. E. (2012). Oxygen Transport By Hemoglobin. Compr. Physiol. 2, 1463-1489. doi: 10.1002/cphy.c080113

Malmberg, P. O., Hlastala, M. P., and Woodson, R. D. (1979). Effect of increased blood-oxygen affinity on oxygen transport in hemorrhagic shock. J. Appl. Physiol. 47, 889-895. doi: 10.1152/jappl.1979.47.4.889

Mangin, O. (2017). High oxygen affinity hemoglobins. Revue Méd. Interne 38, 106-112. doi: 10.1016/j.revmed.2016.06.003

Mihailescu, M.-R., and Russu, I. M. (2001). A signature of the T ? R transition in human hemoglobin. Proc. Natl. Acad. Sci. U.S.A. 98, 3773-3777. doi: 10.1073/ pnas.071493598

Monge, C., and Leon-Velarde, F. (1991). Physiological adaptation to high altitude: oxygen transport in mammals and birds. Physiol. Rev. 71, 1135-1172. doi: 10.1152/physrev.1991.71.4.1135

Monod, J., Wyman, J., and Changeux, J.-P. (1965). On the nature of allosteric transitions: a plausible model. J. Mol. Biol. 12, 88-118. doi: 10.1016/S00222836(65)80285-6

Moore, L. G. (2017). Measuring high-altitude adaptation. J. Appl. Physiol. 123, 1371-1385. doi: 10.1152/japplphysiol.00321.2017
Naeije, R. (2010). Physiological adaptation of the cardiovascular system to high altitude. Prog. Cardiovasc. Dis. 52, 456-466. doi: 10.1016/j.pcad.2010.03.004

Nangaku, M., and Eckardt, K.-U. (2007). Hypoxia and the HIF system in kidney disease. J. Mol. Med. 85, 1325-1330. doi: 10.1007/s00109-007-0278-y

Natarajan, C., Jendroszek, A., Kumar, A., Weber, R. E., Tame, J. R. H., Fago, A., et al. (2018). Molecular basis of hemoglobin adaptation in the high-flying bar-headed goose. PLoS Genet. 14:e1007331. doi: 10.1371/journal.pgen.1007331

Nute, E., Stamatoyannopoulos, G., and Hermodson, M. A. (1974). Hemoglobinopathic erythrocytosis due to a new electrophoretically silent variant, hemoglobin San Diego (109(G11)Val-Met). J. Clin. Invest. 53, 320-328. doi: 10.1172/JCI107553

Otis, A. B., McKerrow, C. B., Bartlett, R. A., Mead, J., McIlroy, M. B., Selverstone, N. J., et al. (1956). Mechanical factors in distribution of pulmonary ventilation. J. Appl. Physiol. 8, 427-443. doi: 10.1152/jappl.1956.8.4.427

Perutz, M. F. (1963). X-ray analysis of hemoglobin. Science 140, 863-869. doi: 10.1126/science.140.3569.863

Perutz, M. F., Shih, D. T., and Williamson, D. (1994). The chloride effect in human haemoglobin. A new kind of allosteric mechanism. J. Mol. Biol. 239, 555-560. doi: 10.1006/jmbi.1994.1394

Phillips, B. A., McConnell, J. W., and Smith, M. D. (1988). The effects of hypoxemia on cardiac output. A dose-response curve. Chest 93, 471-475. doi: 10.1378/ chest.93.3.471

Piiper, J. (1992). Diffusion-perfusion inhomogeneity and alveolar-arterial O2 diffusion limitation: theory. Respir. Physiol. 87, 349-356. doi: 10.1016/00345687(92)90016-P

Pochron, M., Siu, V., Oksenberg, D., and Dufu, K. (2019). Central physiologic mechanisms which augment $\mathrm{O} 2$ release (Bohr Effect and 2,3-DPG Binding) are preserved in the prescence of voxeletor at the therapeutic target of $30 \% \mathrm{Hb}$ modification. HemaSphere 3, 701-702. doi: 10.1097/01.HS9.0000564348.527 40.18

Powell, F. L., Milsom, W. K., and Mitchell, G. S. (1998). Time domains of the hypoxic ventilatory response. Respir. Physiol. 112, 123-134. doi: 10.1016/S00345687(98)00026-7

Prange, H. D., Shoemaker, J. L., Westen, E. A., Horstkotte, D. G., and Pinshow, B. (2001). Physiological consequences of oxygen-dependent chloride binding to hemoglobin. J. Appl. Physiol. 91, 33-38. doi: 10.1152/jappl.2001.91.1.33

Pugh, L. G. C. E., Gill, M. B., Lahiri, S., Milledge, J. S., Ward, M. P., and West, J. B. (1964). Muscular exercise at great altitudes. J. Appl. Physiol. 19, 431-440. doi: 10.1152/jappl.1964.19.3.431

Richardson, T. Q., and Guyton, A. C. (1959). Effects of polycythemia and anemia on cardiac output and other circulatory factors. Am. J. Physiol. Legacy Content. 197, 1167-1170. doi: 10.1152/ajplegacy.1959.197.6.1167

Riggs, A. (1960). The nature and significance of the bohr effect in mammalian hemoglobins. J. Gen. Physiol. 43, 737-752. doi: 10.1085/jgp.43.4.737

Riggs, A. F. (1998). Self-association, cooperativity and supercooperativity of oxygen binding by hemoglobins. J. Exp. Biol. 201, 1073-1085.

Riggs, T. E., Shafer, A. W., and Guenter, C. A. (1973). Acute changes in oxyhemoglobin affinity: effects on oxygen transport and utilization. J. Clin. Invest. 52, 2660-2663. doi: 10.1172/JCI107459

Robertson, C. H., Pagel, M. A., and Johnson, R. L. (1977). The distribution of blood flow, oxygen consumption, and work output among the respiratory muscles during unobstructed hyperventilation. J. Clin. Invest. 59, 43-50. doi: 10.1172/ JCI108620

Romer, L. M., and Polkey, M. I. (2008). Exercise-induced respiratory muscle fatigue: implications for performance. J. Appl. Physiol. 104, 879-888. doi: 10. 1152/japplphysiol.01157.2007

Ross, B. K., and Hlastala, M. P. (1981). Increased hemoglobin-oxygen affinity does not decrease skeletal muscle oxygen consumption. J. Appl. Physiol. 51, 864-870. doi: 10.1152/jappl.1981.51.4.864

Rossoff, L. J., Rebuck, A. S., and Aberman, A. (1980). The hypoxic ventilatory response in patients with high-affinity hemoglobin. Am. J. Respir. Crit. Care Med. 121, 170-172. doi: 10.1164/arrd.1980.121.1.170

Rowell, L. B., and Blackmon, J. R. (1987). Human cardiovascular adjustments to acute hypoxaemia. Clin. Physiol. 7, 349-376. doi: 10.1111/j.1475-097X.1987. tb00179.x

Rumi, E., Passamonti, F., Pagano, L., Ammirabile, M., Arcaini, L., Elena, C., et al. (2009). Blood p50 evaluation enhances diagnostic definition of isolated 
erythrocytosis. J. Intern. Med. 265, 266-274. doi: 10.1111/j.1365-2796.2008. 02014.x

Saha, D., Patgaonkar, M., Shroff, A., Ayyar, K., Bashir, T., and Reddy, K. V. R. (2014). Hemoglobin expression in nonerythroid cells: novel or ubiquitous? Int. J. Inflam. 2014:e803237. doi: 10.1155/2014/803237

Saltin, B., Grover, R. F., Blomqvist, C. G., Hartley, L. H., and Johnson, R. L. (1968). Maximal oxygen uptake and cardiac output after 2 weeks at 4,300 m. J. Appl. Physiol. 25, 400-409. doi: 10.1152/jappl.1968.25.4.400

Samaja, M., Veicsteinas, A., and Cerretelli, P. (1979). Oxygen affinity of blood in altitude Sherpas. J. Appl. Physiol. 47, 337-341. doi: 10.1152/jappl.1979.47.2.337

Schoene, R. B. (2001). Limits of human lung function at high altitude. J. Exp. Biol. 204, 3121-3127. doi: 10.1242/jeb.204.18.3121

Scholander, P. F. (1960). Oxygen transport through hemoglobin solutions. Science 131, 585-590. doi: 10.1126/science.131.3400.585

Schumacker, P. T., Guth, B., Suggett, A. J., Wagner, P. D., and West, J. B. (1985). Effects of transfusion-induced polycythemia on $\mathrm{O} 2$ transport during exercise in the dog. J. Appl. Physiol. 58, 749-758. doi: 10.1152/jappl.1985.58.3.749

Scott, G. R., and Milsom, W. K. (2007). Control of breathing and adaptation to high altitude in the bar-headed goose. Am. J. Physiol. Regul. Integr. Comp. Physiol. 293, R379-R391. doi: 10.1152/ajpregu.00161.2007

Sheel, A. W., Derchak, P. A., Morgan, B. J., Pegelow, D. F., Jacques, A. J., and Dempsey, J. A. (2001). Fatiguing inspiratory muscle work causes reflex reduction in resting leg blood flow in humans. J. Physiol. 537, 277-289. doi: 10.1111/j.1469-7793.2001.0277k.x

Shepherd, J. R. A., Dominelli, P. B., Roy, T. K., Secomb, T. W., Hoyer, J. D., Oliveira, J. L., et al. (2019). Modelling the relationships between haemoglobin oxygen affinity and the oxygen cascade in humans. J. Physiol. 597, 4193-4202. doi: 10.1113/JP277591

Siebenmann, C., and Lundby, C. (2015). Regulation of cardiac output in hypoxia. Scand. J. Med. Sci. Sports 25, 53-59. doi: 10.1111/sms.12619

Simonson, T. S., Wei, G., Wagner, H. E., Wuren, T., Bui, A., Fine, J. M., et al. (2014). Increased blood-oxygen binding affinity in Tibetan and Han Chinese residents at 4200 m. Exp. Physiol. 99, 1624-1635. doi: 10.1113/expphysiol.2014.080820

Stewart, G. M., Chase, S., Cross, T. J., Wheatley-Guy, C. M., Joyner, M., Curry, T., et al. (2020). Effects of an allosteric hemoglobin affinity modulator on arterial blood gases and cardiopulmonary responses during normoxic and hypoxic lowintensity exercise. J. Appl. Physiol. 128, 1467-1476. doi: 10.1152/japplphysiol. 00185.2019

Stewart, G. M., Cross, T. J., Joyner, M. J., Chase, S. C., Curry, T., Lehrer-Graiwer, J., et al. (2021). Impact of pharmacologically left shifting the oxygen-hemoglobin dissociation curve on arterial blood gases and pulmonary gas exchange during maximal exercise in hypoxia. High Alt. Med. Biol. 22, 249-262. doi: 10.1089/ ham.2020.0159

Storz, J. F. (2016). Hemoglobin-oxygen affinity in high-altitude vertebrates: is there evidence for an adaptive trend? J. Exp. Biol. 219, 3190-3203. doi: 10.1242/jeb. 127134

Storz, J. F. (2021). High-Altitude adaptation: mechanistic insights from integrated genomics and physiology. Mol. Biol. Evol. 38, 2677-2691. doi: 10.1093/molbev/ msab064

Storz, J. F., Scott, G. R., and Cheviron, Z. A. (2010). Phenotypic plasticity and genetic adaptation to high-altitude hypoxia in vertebrates. J. Exp. Biol. 213, 4125-4136. doi: 10.1242/jeb.048181

Tashi, T., Feng, T., Koul, P., Amaru, R., Hussey, D., Lorenzo, F. R., et al. (2014). High altitude genetic adaptation in Tibetans: no role of increased hemoglobinoxygen affinity. Blood Cells Mol. Dis. 53, 27-29.

Tezel, T. H., Geng, L., Lato, E. B., Schaal, S., Liu, Y., Dean, D., et al. (2009). Synthesis and secretion of hemoglobin by retinal pigment epithelium. Invest. Ophthalmol. Vis. Sci. 50, 1911-1919. doi: 10.1167/iovs.07-1372

Thomson, J. M., Dempsey, J. A., Chosy, L. W., Shahidi, N. T., and Reddan, W. G. (1974). Oxygen transport and oxyhemoglobin dissociation during prolonged muscular work. J. Appl. Physiol. 37, 658-664. doi: 10.1152/jappl.1974.37.5.658

Tymko, M. M., Tremblay, J. C., Bailey, D. M., Green, D. J., and Ainslie, P. N. (2019). The impact of hypoxaemia on vascular function in lowlanders and high altitude indigenous populations. J. Physiol. 597, 5759-5776. doi: 10.1113/JP277191

Tyuma, I., Shimizu, K., and Imai, K. (1971). Effect of 2,3-diphosphoglycerate on the cooperativity in oxygen binding of human adult hemoglobin. Biochem. Biophys. Res. Commun. 43, 423-428. doi: 10.1016/0006-291X(71)90770-4
Valeri, C. R., Rorth, M., Zaroulis, C. G., Jakubowski, M. S., and Vescera, S. V. (1975). Physiologic effects of transfusing red blood cells with high or low affinity for oxygen to passively hyperventilated, anemic baboons: systemic and cerebral oxygen extraction. Ann. Surg. 181, 106-113.

Versmold, H., Seifert, G., and Riegel, K. P. (1973). Blood oxygen affinity in infancy: the interaction of fetal and adult hemoglobin, oxygen capacity, and red cell hydrogen ion and 2,3-diphosphoglycerate concentration. Respir. Physiol. 18, 14-25. doi: 10.1016/0034-5687(73)90018-2

Wagner, P. D. (1997). Insensitivity of VO2max to hemoglobin-P50 at sea level and altitude. Respir. Physiol. 107, 205-212. doi: 10.1016/s0034-5687(96)02512-1

Wagner, P. D. (2010). Operation Everest II. High Alt. Med. Biol. 11, 111-119. doi: $10.1089 /$ ham.2009.1084

Ward, J. P. T. (2008). Oxygen sensors in context. Biochim. Biophys. Acta (BBA) Bioenerget. 1777, 1-14. doi: 10.1016/j.bbabio.2007.10.010

Wasserman, K. (1978). The carotid bodies: pathologic or physiologic? Chest 73, 564-566. doi: 10.1378/chest.73.5.564

Wearing, O. H., Ivy, C. M., Gutiérrez-Pinto, N., Velotta, J. P., Campbell-Staton, S. C., Natarajan, C., et al. (2021). The adaptive benefit of evolved increases in hemoglobin-O2 affinity is contingent on tissue $\mathrm{O} 2$ diffusing capacity in high-altitude deer mice. BMC Biol. 19:128. doi: 10.1186/s12915-021-0 1059-4

Weber, R. E., and Campbell, K. L. (2011). Temperature dependence of haemoglobin-oxygen affinity in heterothermic vertebrates: mechanisms and biological significance. Acta. Physiol. 202, 549-562. doi: 10.1111/j.1748-1716. 2010.02204.X

Weber, R. E., Jessen, T. H., Malte, H., and Tame, J. (1993). Mutant hemoglobins (alpha 119-Ala and beta 55-Ser): functions related to high-altitude respiration in geese. J. Appl. Physiol. 75, 2646-2655. doi: 10.1152/jappl.1993.75.6.2646

Wehrlin, J. P., and Hallén, J. (2006). Linear decrease in VO2max and performance with increasing altitude in endurance athletes. Eur. J. Appl. Physiol. 96, 404-412. doi: 10.1007/s00421-005-0081-9

Weil, J. V., and Zwillich, C. W. (1976). Assessment of ventilatory response to hypoxia methods and interpretation. Chest 70, 124-128. doi: 10.1378/chest.70. 1_Supplement.124

Weisse, A. B., Calton, F. M., Kuida, H., and Hecht, H. H. (1964). Hemodynamic effects of normovolemic polycythemia in dogs at rest and during exercise. Am. J. Physiol. Legacy Content 207, 1361-1366. doi: 10.1152/ajplegacy.1964.207.6. 1361

West, J. (1984). Human physiology at extreme altitudes on Mount Everest. Science 223, 784-788. doi: 10.1126/science.6364351

West, J. B. (2006). Human responses to extreme altitudes. Integr. Comp. Biol. 46, 25-34. doi: 10.1093/icb/icj005

West, J. B. (2010). American medical research expedition to everest. High Alt. Med. Biol. 11, 103-110. doi: 10.1089/ham.2009.1089

Wieth, J. O., Andersen, O. S., Brahm, J., Bjerrum, P. J., Borders, C. L., Keynes, R. D., et al. (1982). Chloride-bicarbonate exchange in red blood cells: physiology of transport and chemical modification of binding sites. Phil. Trans. R. Soc. Lond. 299, 383-399. doi: 10.1098/rstb.1982.0139

Winslow, R. M. (2007). The role of hemoglobin oxygen affinity in oxygen transport at high altitude. Respiratory Physiol. Neurobiol. 158, 121-127. doi: 10.1016/j. resp.2007.03.011

Winslow, R. M., Monge, C. C., Statham, N. J., Gibson, C. G., Charache, S., Whittembury, J., et al. (1981). Variability of oxygen affinity of blood: human subjects native to high altitude. J. Appl. Physiol. 51, 1411-1416. doi: 10.1152/ jappl.1981.51.6.1411

Winslow, R. M., Samaja, M., and West, J. B. (1984). Red cell function at extreme altitude on Mount Everest. J. Appl. Physiol. 56, 109-116. doi: 10.1152/jappl. 1984.56.1.109

Woodson, R. D., and Auerbach, S. (1982). Effect of increased oxygen affinity and anemia on cardiac output and its distribution. J. Appl. Physiol. 53, 1299-1306. doi: 10.1152/jappl.1982.53.5.1299

Woodson, R. D., Torrance, J. D., Shappell, S. D., and Lenfant, C. (1970). The effect of cardiac disease on hemoglobin-oxygen binding. J. Clin. Invest. 49, 1349-1356. doi: 10.1172/JCI106351

Woodson, R. D., Wranne, B., and Detter, J. C. (1973). Effect of increased blood oxygen affinity on work performance of rats. J. Clin. Invest. 52, 2717-2724. doi: 10.1172/JCI107466 
Wranne, B., Berlin, G., Jorfeldt, L., and Lund, N. (1983). Tissue oxygenation and muscular substrate turnover in two subjects with high hemoglobin oxygen affinity. J. Clin. Invest. 72, 1376-1384. doi: 10.1172/JCI1 11094

Wranne, B., Nordgren, L., and Woodson, R. D. (1974). Increased blood oxygen affinity and physical work capacity in man. Scand. J. Clin. Lab. 33, 347-352. doi: 10.1080/00365517409082505

Yalcin, O., and Cabrales, P. (2012). Increased hemoglobin O2 affinity protects during acute hypoxia. Am. J. Physiol. Heart Circ. 303, H271-H281. doi: 10.1152/ ajpheart.00078.2012

Yhap, E. O., Wright, C. B., Popovic, N. A., and Alix, E. C. (1975). Decreased oxygen uptake with stored blood in the isolated hindlimb. J. Appl. Physiol. 38, $882-885$.

Zak, S. J., Brimhall, B., Jones, R. T., and Kaplan, M. E. (1974). Hemoglobin andrew-minneapolis $\alpha$ A2 $32144 \mathrm{Lys} \rightarrow$ Asn: a new high-oxygen-affinity mutant human hemoglobin. Blood 44, 543-549. doi: 10.1182/blood.V44.4. 543.543
Conflict of Interest: The authors declare that the research was conducted in the absence of any commercial or financial relationships that could be construed as a potential conflict of interest.

Publisher's Note: All claims expressed in this article are solely those of the authors and do not necessarily represent those of their affiliated organizations, or those of the publisher, the editors and the reviewers. Any product that may be evaluated in this article, or claim that may be made by its manufacturer, is not guaranteed or endorsed by the publisher.

Copyright (c) 2022 Webb, Dominelli, Baker, Klassen, Joyner, Senefeld and Wiggins. This is an open-access article distributed under the terms of the Creative Commons Attribution License (CC BY). The use, distribution or reproduction in other forums is permitted, provided the original author(s) and the copyright owner(s) are credited and that the original publication in this journal is cited, in accordance with accepted academic practice. No use, distribution or reproduction is permitted which does not comply with these terms. 